\title{
DE LÉVI-STRAUSS A M.A.U.S.S. - MOVIMENTO ANTIUTILITARISTA NAS CIÊNCIAS SOCIAIS Itinerários do dom*
}

\section{Paulo Henrique Martins}

* Este artigo constitui um balanço provisório dos dez anos de difusão de uma abordagem não-estruturalista sobre o dom, que destaca a liberdade da ação sem negligenciar o valor da obrigação. Assinalamos o período de dez anos pois o ano de 1998 é um marco para alguns eventos que tiveram relevância na difusão de uma nova abordagem sobre o dom: em primeiro lugar, o lançamento do livro O espirito da dádiva, de Jacques Godbout em colaboração com Alain Caillé, que atualiza o valor do dom para explicar fenômenos sociais modernos como a solidariedade social e a doação de órgãos, por exemplo; em segundo, a visita de Godbout ao Brasil como conferencista da Anpocs; em terceiro lugar, a publicação na Revista Brasileira de Ciências Sociais de autores que se mostram simpáticos à revisão do debate. Assim no número 38 da RBCS de 1998 foram publicados três textos que, no nosso entender, legitimam direta ou indiretamente um paradigma do dom: o artigo de Alain Caillé "Nem holismo nem individualismo metodológico: Marcel Mauss e o pa-

Artigo recebido em janeiro/2007

Aprovado em dezembro/2007 radigma do dom" e o de Jacques Godbout, "Introdução à dádiva", que tratam diretamente do assunto; e o artigo de Gabriel Cohn, "As diferenças finais: de Simmel a Luhman", no qual o autor propõe revisitar Simmel a partir de sua proximidade de autores como Mauss - e numa outra perspectiva também Luhman -, que se recusam a aceitar um paradigma baseado na centralidade da troca na vida social, que recusam o reducionismo econômico e que valorizam as relações recíprocas sempre renovadas, sem perder de vista a totalidade. Deve-se ainda relacionar na linha de textos não estruturalistas sobre o dom o artigo de Lygia Sigaud, "As vicissitudes do Ensaio sobre o dom”, de 1999. Embora não dialogando diretamente com os autores do M.A.U.S.S., a autora realiza uma brilhante revisão da leitura empreendida por Lévi-Strauss sobre o dom.

\section{Percepções do dom}

Qual o lugar dos estudos sobre o dom ou a dádiva ${ }^{1}$ no interior da Teoria Social? No caso brasi- 
leiro, a difusão dos estudos sobre o dom está condicionada absolutamente pela presença do estruturalismo antropológico como filtro mediador? Ou existem outras leituras também legítimas que valorizem o dom numa perspectiva disciplina mais ampla, envolvendo a sociologia, a economia, a filosofia e a política e que sejam relevantes para a renovação do pensamento teórico?

No desenvolvimento deste artigo defenderemos o caráter interdisciplinar e interacionista dos estudos sobre o dom, reforçando a tese, já proposta por outros autores, de entendê-lo como fundamento de um novo paradigma, ${ }^{2}$ como base de uma ciência moral humanista cujas raízes estão inscritas não apenas na trajetória de Mauss, mas, antes, no humanismo de Durkheim. ${ }^{3}$ Pretendemos reforçar a leitura não-estruturalista da dádiva, permitindo entendê-la como uma teoria de reciprocidade aberta e ambivalente. Não-estruturalista porque sem negar o valor da lingüística estrutural esta outra abordagem do dom considera igualmente válidas as correntes do pensamento que se desenvolveram em paralelo ao estruturalismo. Tal abordagem alternativa distancia-se do tratamento tradicional oferecido pelo estruturalismo - que enfatiza no dom uma função de troca relativamente rígida -, para realçar no vínculo social um paradoxo entre a regra e a espontaneidade, entre a liberdade e a obrigação. Por se abrir à liberdade e à criatividade do sujeito social, essa visão não-estruturalista é também antiutilitarista, revelando-se como um recurso explicativo importante para a crítica dos discursos que reduzem os motivos da ação social a um utilitarismo material - o interesse econômico no caso do mercado - ou a um utilitarismo normativo - o respeito incondicional à norma no caso de sistemas estatais tecnocráticos. Na perspectiva aqui assinalada, o dom aparece como uma alternativa a esses dois paradigmas tipicamente modernos, o do mercado e o do Estado.

Tal leitura alternativa que identifica o dom como um sistema aberto de reciprocidades permite associar Marcel Mauss a autores interacionistas como Simmel, lembra Gabriel Cohn, que valorizam "relações recíprocas sempre renovadas para além do seu impulso inicial" (Cohn, 1998, p. 54). Nesta associação podemos também relacionar autores como Mead, Cooley e Goffman, que são referências na origem e no desenvolvimento dos estudos interacionistas.

A desconstrução da abordagem estruturalista do dom contribui para revelar, por outro lado, o vínculo do dom com o novo movimento teórico, expressão vulgarizada por Jeffrey Alexander para explicar que a renovação da teoria sociológica passa necessariamente pela consideração da hermenêutica científica, do discurso e da cultura (Alexander, 1987). Sobre este último ponto - uma maior associação do social com a cultura -, o dom aparece necessariamente como operador simbólico estratégico do novo movimento teórico pelo fato de situar-se nas fronteiras de disciplinas como a etnologia, a antropologia e a sociologia.

Neste texto, partimos do princípio de que o novo movimento teórico tem desdobramentos nas ciências sociais que se reportam necessariamente a certas experiências de descontinuidades epistêmicas no campo científico: uma, mais restrita, diz respeito à virada lingüística ocorrida entre os anos de 1970 e 1980 (Dosse, 1997); outra, mais ampla, trata da virada epistemológica que remete aos anos de 1940, mais precisamente aos fenômenos trágicos da Segunda Guerra Mundial e à crise da filosofia da história (Merleau-Ponty, 1960). Nesta segunda e mais abrangente leitura, o novo movimento teórico afirma-se não apenas com relação ao estruturalismo, mas, igualmente, com relação a uma série de outras correntes de pensamento que se desenvolveram em paralelo ao estruturalismo como a teoria crítica da escola de Frankfurt, a filosofia política crítica do totalitarismo de Hanna Arendt, Claude Lefort e Cornelius Castoriadis, a filosofia analítica inglesa de Wittgenstein, que tem uma ponte na França mediante Ricoeur e as escolas interacionistas norte-americanas de Blumer, Goffman e Garfinkel. Neste texto, pretendemos situar os estudos sobre o dom nesta ótica mais ampla que inclui o estruturalismo, mas que se enraíza em um diálogo mais amplo com outras correntes teóricas.

De modo geral, os esforços de divulgação dos estudos sobre o dom encontram dificuldades de várias ordens, dependendo dos contextos sóciohistóricos de sua recepção. Desde já, é importante esclarecer que a revisão dos estudos sobre o tema no pensamento social, no Brasil, exige não se reduzir a relação entre dom e troca no campo acadê- 
mico à ótica sugerida pela antropologia estrutural e por Lévi-Strauss, incluindo outras percepções científicas e não-científicas do tema. Há que se chamar atenção sobre as implicações semânticas da dádiva, isto é, sua recepção e difusão no imaginário popular através da reprodução da tradição católica. Há que se ressaltar ainda as reações dos defensores do utilitarismo econômico contra uma teoria eminentemente antiutilitarista como esta, o que tem sido ressaltado por vários autores, embora no Brasil este debate necessite de maior vigor.

Há, em suma, três focos de resistência contra uma difusão mais empolgante do dom no pensamento crítico: uma tem a ver com a representação religiosa do termo dom, outra, com a reação utilitarista e neoliberal contra o pensamento humanista e associativo e, em terceiro lugar, no interior do campo acadêmico, a reação dos simpatizantes da antropologia estrutural contra releituras da obra de Mauss a partir de um enfoque sociológico e político. É de se ressaltar que, em conjunto, tais resistências inibem o avanço do debate, exigindo certo esforço para desfazer os nós criados em torno desse tema. Vejamos a seguir cada um deles mais de perto.

\section{Dom e senso comum}

Sobre o primeiro aspecto, a forte vinculação do termo dom com o senso comum religioso, já tratamos deste assunto em outra oportunidade, em particular no artigo "A sociologia de Marcel Mauss: dádiva, simbolismo e associação" (Martins, 2005). Embora este tema não seja fundamental neste artigo, é de se reconhecer que parte das dificuldades de difusão dos estudos sobre a dádiva no Brasil, está ligada à forte associação deste termo com a religiosidade popular e com a influência do catolicismo tradicional sobre o imaginário da doação. No caso dos países influenciados pela cultura religiosa ibérica e, em particular, a lusitana, a forte associação da palavra dom com o imaginário católico tradicional constitui um elemento inibidor da sua compreensão científica, ${ }^{4}$ demonstrando a força do senso comum na representação deste fenômeno socioantropológico. De fato, no imaginário brasileiro, esta palavra está fortemente associada às idéias de caridade, de virtude divina, de angelismo, isto é, de identificação da idéia de dom com uma interpretação espiritualista do ser humano. Embora tal compreensão religiosa do dom pelo senso comum não deva ser desprezada, pretendemos demonstrar que esta é apenas uma leitura do termo, e que não é a mais importante.

\section{Dom e utilitarismo econômico}

Uma segunda dificuldade para a difusão deste debate na Teoria Social tem relação com o reducionismo econômico e com as resistências de certas teorias individualistas - como as da escolha racional e do individualismo metodológico -, que não identificam no sistema da dádiva uma categoria sociológica que contemple a presença da racionalidade instrumental que elas tanto valorizam. Este tema tem recebido uma atenção bastante ampla dos críticos, envolvendo o próprio projeto do M.A.U.S.S. (Movimento Antiutilitarista nas Ciências Sociais) (Caillé, 1989 e 1998; Godbout, 1998a e 1998b), que defende a idéia de que o sistema do dom não é arbitrário e que se abre a diversas racionalidades, entre outras, a do interesse instrumental. Mas considerando o peso do utilitarismo nas ciências sociais, inclusive no Brasil, não se pode deixar de fazer uma alusão à dificuldade que o mesmo significa na divulgação dos novos estudos sobre o dom. Pois, para os simpatizantes das teorias acima lembradas a dádiva seria uma "teoria menor" ao pressupor que a ação social se fundaria em mera generosidade e altruísmo. Ao contrário, propõem tais críticos, os homens seriam, sobretudo, indivíduos egoístas que agem de acordo com seus próprios interesses, não existindo a gratuidade e o desinteresse. Muitos dos esforços dos estudiosos sobre o dom, ao menos nos anos de 1980, foram direcionados para provar que a ação social não se reduz apenas ao interesse material, havendo também o interesse pelo poder, pelo prestígio e pelos bens simbólicos em geral. Além do fato de que o interesse não é apenas autocentrado, mas também heterocentrado. Este tipo de discussão abre necessariamente os estudos sobre a dádiva para a tradição interacionista, assunto que será aprofundado mais adiante. 


\section{Dom e estruturalismo antropológico}

Há uma dificuldade respeitável dentro do próprio campo das ciências sociais para se atualizar a compreensão do Ensaio sobre a dádiva: forma e razão das trocas nas sociedades arcaicas (em Mauss, 2003), desfazendo a redução do dom à troca, como foi feito por Lévi-Strauss a partir de uma leitura marcada pela influência da teoria lingüística, com impacto importante sobre os estudos antropológicos. ${ }^{5}$ O pensamento crítico demonstra dificuldades para se libertar da leitura estruturalista na medida em que houve uma revitalização da dádiva, nos anos de 1980, a partir da idéia de que a mesma contém uma explicação mística da troca (Sigaud, 1999, p. 113). A persistência do estruturalismo através de novas leituras que atualizam sua essência dificulta os esforços de se retomar o Ensaio sobre a dádiva sob outro ângulo teórico que realce suas dimensões sociológicas e polítidcas que são necessárias para a crítica ao utilitarismo.

De fato, existem divergências que tendem a situar em lados opostos aqueles estudiosos simpatizantes da vinculação dos estudos sobre o dom à antropologia estrutural, e os que sustentam possuir a dádiva um sentido mais universal, que interessa também à sociologia e às ciências sociais como um todo. Para os que defendem haver uma estreita associação do dom com a antropologia estrutural, o interlocutor privilegiado de Mauss seria Lévi-Strauss, seu discípulo mais conhecido, e os tradutores deste pai da antropologia estrutural que passou a considerar a reciprocidade como uma forma de intercâmbio simétrico (Sabourin, 2004, p. 78). Nesta ótica, a disputa entre antropólogos estruturalistas e demais cientistas sociais sobre a herança de Mauss gera prejuízos em termos de difusão do dom como uma teoria do conhecimento extremamente relevante, por exemplo, para a crítica do pensamento hegemônico, o utilitarismo econômico. ${ }^{6}$ Ao deixar o dom prisioneiro de uma disputa acadêmica e de um quadro de análise rígido, perde-se de vista seu valor prático para a crítica teórica no sentido de repensar o direito, a economia e a política.

Mas, a partir dos fins dos anos de 1970, com as pressões políticas e teóricas a favor do "retorno do sujeito" - não de um sujeito ontológico, mas de sujeitos abertos à diferenciação e à diversidade, como defendem os autores pós-estruturalistas -, as teses do dom como uma função estrutural fixa passam a ser revistas. A crítica tem como fonte central o reconhecimento da liberdade do sujeito social na definição de suas obrigações morais e nos processos de construção de alianças e de formulação de novos sistemas de reciprocidade. No Brasil, deve ser destacada a crítica acertada que faz Lygia Sigaud à tentativa de Lévi-Strauss de reduzir as obrigações que via Mauss nas ações de dar-receber-retribuir a uma teoria de troca rígida (Sigaud, 1999, p. 106), o que constitui uma contribuição importante para se avançar na reinterpretação dos estudos sobre o dom.

\section{Sintese preliminar}

As resistências à renovação dos estudos sobre a dádiva revelam a força de crenças, preconceitos e desinformações que distorcem a recepção correta do seu sentido. Nenhuma das objeções tradicionais constitui, porém, um impedimento para que se resgate o valor do dom na crítica social. É o que faremos, a seguir, procurando demonstrar que no dom há uma teoria da reciprocidade aberta e flexível, que permite revelar a complexidade das motivações presentes na ação social, que favorece resgatar a experiência e o valor da ação intersubjetiva, que favorece, ainda, articular o saber comum e o saber científico e que, por fim, valoriza o cotidiano sem desprezar as articulações entre os planos micro e macro.

Nessa perspectiva, a confusão semântica gerada pelo termo dom não deve ser considerada uma dificuldade para seu reconhecimento como um sistema de ação primário presente em todas as sociedades tradicionais e modernas, como demonstrou Mauss no seu Ensaio sobre a dádiva. A co-presença cultural e histórica deste sistema motivou Caillé a propor que ele constitui o paradigma por excelência, ou seja, um paradigma arcaico e anterior àqueles do mercado e do Estado, que seriam derivações do dom (Caillé, 2002b; Godbout, 2002). Este caráter universal do dom, mas, ao mesmo tempo, aberto à diversidade, à liberdade de o sujeito social desfazer a aliança segundo suas motivações particulares dadas por certo quadro normativo, permite propor, igualmente, o dom como 
base de uma ciência moral humanista, que possibilita sua articulação com a solidariedade e com a democracia. Desse modo, a discussão sobre o dom pode se libertar progressivamente dos velhos condicionantes interpretativos, que o definiam como uma função simbólica rígida, para receber nova acolhida na teoria social.

Mas o trabalho de desconstrução das resistências assinaladas - a tradição religiosa católica, o utilitarismo econômico e a antropologia estrutural - não pode ser feito apenas pela declaração de boas intenções reconciliando o dom e o novo movimento teórico. É importante entender que as leituras diversas sobre este sistema - vulgares ou científicas - resultam de um trabalho de adaptação e recriação de conceitos a partir de um contexto que é sempre mutante. Nesse sentido, entendemos que o desenvolvimento desta reflexão deve considerar alguns passos: um deles, os sentidos da tradução e do contexto que delimitam o trabalho de adaptação e recriação de idéias apropriadas; o outro, o contexto no qual foi produzido o Ensaio sobre a dádiva, que compõe a matriz inspiradora do debate para todos os envolvidos. Tal contextualização permite entender que a obra de Mauss não tem apenas valor etnológico ou antropológico, mas uma grande atualidade sociológica para a explicação das sociedades contemporâneas.

\section{Vicissitudes de uma interpretação não-estruturalista do dom}

O resgate dos estudos sobre o dom numa perspectiva não-estruturalista deve considerar a proposição sustentada pelos teóricos da fenomenologia de que a realidade objetiva - que o estruturalismo definiu como sendo uma invariante simbólica - é sempre uma projeção do pensamento, e que sua apreensão objetivada sempre escapa dos métodos aplicados. Não apenas por haver uma relação de dependência mútua entre o sujeito e o objeto, mas porque o próprio método é sempre condicionado pela experiência vivida do sujeito social. Esta tese apresenta de imediato uma reflexão filosófica sobre a relação entre o sujeito e o objeto do conhecimento e uma outra de caráter epistemológico a respeito da importância do contexto para a produção e a adaptação de idéias e valores do método lingüístico na organização de um conhecimento objetivo.

A crítica filosófica referente aos status do sujeito e do objeto é ampla, diga-se de passagem, estando na base de contribuições hermenêuticas e fenomenológicas de grandes autores do século XX, como Husserl, Heidegger, Sartre, Bergson, Wittgenstein, Austin, Ricoeur, entre outros. Mas gostaríamos de nos deter em Maurice MerleauPonty, que escreveu um instigante artigo intitulado "De Mauss à Claude Lévi-Strauss" (1960). Para ele, os lugares do sujeito e do objeto apresentam uma conotação particular quando se pensam as relações entre os seres humanos e a invenção de um mundo compartilhado. Nessa direção, o reconhecimento do corpo fenomenal - ou corpo subjetivo - é uma condição para se superar o dualismo citado. Entender este corpo não mais como mero suporte mecânico, mas como capacidade expressiva, permite que o sujeito se perceba imediatamente no outro e que ele e o outro sejam seres igualmente atravessados pelo mesmo mundo.

O mundo fenomenológico não é o ser puro, mas o sentido que transparece na intersecção de minhas experiências e daquelas do outro, pelas engrenagens de umas sobre as outras, ele é logo inseparável da subjetividade e da intersubjetividade que conseguem sua unidade pela retomada de minhas experiências passadas nas minhas experiências presentes, pela experiência do outro na minha (Merleau-Ponty, 1999, p. XV).

Na percepção do outro, afirma Merleau-Ponty em outra passagem, eu atravesso em intenção a distância infinita "que separa sempre minha subjetividade do outro e que me permite constatar uma outra presença no mundo" (Idem, p. 494). ${ }^{7}$

No artigo citado, o autor reinterpreta de forma ambivalente as idéias de sujeito e objeto por meio das noções de estrutura e de vivido, revelando a complexidade do debate naquele contexto histórico de organização do pensamento estruturalista francês. Em certo momento, defende, por exemplo, a idéia de experiência na antropologia como sendo a expressão de nossa inserção como sujeitos sociais em um todo que nos precede, no qual já haveria uma síntese que delimitaria nossa investigação laboriosa, "pois vivemos na unidade de uma só vida todos os sistemas de que nossa cultura é 
feita" (Idem, 1960, p. 132). Porém, num momento seguinte, afirma que na outra ponta do campo da antropologia, em certos sistemas complexos, as estruturas se quebram e se abrem; a sociedade deixa de aparecer como uma segunda natureza, cada um sendo convidado a definir seu próprio sistema de troca; as fronteiras da cultura se rompem, a função simbólica perde sua rigidez e se estabelece um uso profano da vida (Idem, p. 141). Como se percebe, as reflexões do autor refletem neste período a preocupação de resgatar a dimensão sistêmica da vida social, mas sem perder de vista o vivido. Daí ele falar de uma dupla experiência: antropológica e estrutural, sociológica e vivencial. Lévi-Strauss teve grande sucesso no primeiro caminho, isto é, na busca de matematizar e codificar as funções simbólicas fundamentais da experiência cultural. Mas esta opção, veremos, levou-o inevitavelmente a desvalorizar o vivido e a experiência da intersubjetividade na configuração das regras objetivas, inclusive aquelas da linguagem.

A questão que podemos colocar, desde logo, é a seguinte: até que ponto Lévi-Strauss "trai" Mauss abandonando uma leitura fenomenológica da experiência para vagar pela lingüística estrutural? A resposta não é simples uma vez que Lévi-Strauss insiste em sua fidelidade a Mauss, seja quando fala das relações entre a sociologia e a psicologia, considerando a experiência individual em face da coletiva, seja quando discute a idéia do fato social total, o qual permitiria observar no comportamento dos indivíduos as influências sociológicas, históricas e fisiopsicológicas, como o faz no texto introdutório aos escritos reunidos de Mauss sob o título Sociologia e antropologia (2003). Assim, se nos dedicarmos ao estudo do concreto e do completo, diz ele, "devemos necessariamente perceber que o verdadeiro não é a prece ou o direito, mas o melanésio desta ou daquela ilha, Roma ou Atenas" (Lévi-Strauss, 2003, p. 24). Ou seja, há aqui a valorização da experiência individual, mas de uma experiência que se submete às obrigações coletivas, o que também é sugerido por Mauss no Ensaio... O autor também não trai Mauss ao concluir que para "apreender um fato social total é preciso apreendê-lo totalmente", isto é, como uma "coisa" da qual faz parte a apreensão subjetiva (Idem, p. 26). A distância com relação a Mauss, no nosso entender, aparece quando ele esquece que seu mestre pensou o dom não apenas como uma linguagem simbólica mas como um caminho teórico de crítica ao utilitarismo mercantil e favorável a um projeto associacionista, como veremos adiante. Esta distância ocorre quando Lévi-Strauss busca superar a dualidade entre sociedade e indivíduo, entre sujeito e objeto, entre consciente e inconsciente, recorrendo à lingüística estrutural para propor um método rigoroso de análise do empírico. Ele tenta atribuir a Mauss esta preocupação com regras precisas, com "ciclos de reciprocidade cujas leis são doravante conhecidas" (Idem, pp. 31-33), concluindo que as trocas não estão nos fatos, mas apenas na aplicação do método aos fatos.

Quando decide matematizar as formas simbólicas e considerá-las realidades universais apreendidas pelo método lingüístico, como é o caso do tabu do incesto, independentemente das vicissitudes históricas e particulares, o autor necessariamente rompe com a tradição fenomenológica e hermenêutica para propor um novo método de análise combinatória que perde de vista o valor do vivido. Neste momento, o pai da antropologia estrutural, sem desconsiderar a relação orgânica entre sujeito e objeto, opta por uma compreensão que se afasta da determinação do sujeito para valorizar um sistema de interpretação, a antropologia estrutural, que explique simultaneamente os aspectos físico, fisiológico, psíquico e sociológico de todas as condutas (Idem, p. 24).

Esta primeira reflexão de caráter filosófico leva-nos, por conseguinte, a outra de caráter epistemológico relativa ao contexto de produção do conhecimento e da experiência. A presença perceptiva no mundo, na perspectiva de MerleauPonty, serve, de fato, para esclarecer algo decisivo no desenvolvimento deste artigo, em particular o esforço de reorganização dos estudos sobre o dom no interior do novo movimento teórico. Pois contra este reducionismo lingüístico, insurgem-se aqueles que defendem uma outra leitura do dom, leitura que resgate a dimensão plural e permanentemente renovadora da experiência do vivido, da liberdade do sujeito na organização da ordem do mundo.

Na perspectiva da fenomenologia, o trabalho intelectual não se produz a partir de um lugar abstrato, mas de um lugar visível, mesmo que os materiais utilizados para a criação intelectual, como 
memórias, vivências e crenças, sejam muitas vezes invisíveis para o autor. Esta é uma questão fecunda que suscita acima de tudo a busca de sentido fornecida pela nossa experiência cultural, psicológica, emocional, política e social, pela vivência no cruzamento da experiência do outro. Este sentido é determinado e singularizado pela expressividade do sujeito, pelo modo como se faz presente no mundo no interior de um contexto intersubjetivo particular, único caminho para se evitar "a ilusão de ver o que não se vê" (Merleau-Ponty, 1964b, p. 20), de desconhecer o impacto sobre os discursos objetivados, inclusive o científico de uma experiência comunitária, associativa, local, nacional ou transnacional que marca de modo particular a percepção do sujeito no mundo.

Essas reflexões buscam situar um aspecto crucial na organização do pensamento crítico, a saber, a importância de contextualizar as condições de produção do conhecimento, dando conta simultaneamente do lugar de quem pensa, do outro pensado - que é pensante também - e daquilo que observa. A dificuldade de sair do pensamento operacional fundado na idéia de um corpo objetivado - mesmo que seja o corpo simbólico - para entrar num pensamento crítico - inspirado num corpo fenomenal e aberto à intersubjetividade exige que o trabalho intelectual esteja sensibilizado para a importância de contextualização do pensamento, isto é, de analisar sob que condições ocorrem os trabalhos de tradução, adaptação e criação de idéias e teorias. Apenas a partir de tal sensibilização é que as experiências de criação do conhecimento, geradas em contextos sócio-históricos diversos, podem ser reorganizadas, respeitando-se as exigências, os modos de percepção e de vivências de outros contextos.

Semelhante discussão é decisiva para se entender que muitas vezes a busca de originalidade teórica apenas camufla as dificuldades dos autores de contextualizar o pensamento. Vale a pena ilustrar este debate com uma situação prática exposta por Jessé de Sousa nas releituras que fez das obras de Gilberto Freyre e de Roberto DaMatta, tradicionalmente considerados como autores que oferecem análises originais da realidade brasileira (Souza, 2001a, 2001b). Demonstra Souza que apesar das tentativas de alguns de apontar Freyre e DaMatta como autores que pensam o Brasil a partir de um mesmo lugar, na prática enquanto o segundo privilegia um esquema dicotômico de dois sistemas - o europeu individualista e o patriarcal e pessoal - para explicar a realidade sociocultural brasileira, Freyre entende que ao longo da modernização brasileira os valores impessoais da re-europeização teriam vencido os valores pessoais do passado (Souza, 2001a, pp. 197-198). Essas considerações são importantes para lembrar que não basta que os processos de tradução simbólica de narrativas e esquemas explicativos sejam marcadamente originais, sendo fundamental entender como se fundam as pessoas morais, as estruturas de self que delimitam a percepção moral e cognitiva. ${ }^{8}$

O problema do trabalho intelectual não está apenas, pois, em destacar as diferenças culturais e de tentar padronizar certos registros teóricos como se eles fossem universais. Isto o estruturalismo antropológico o fez. O problema está em esquecer que a própria enunciação de tais registros já está marcada por certa presença perceptiva, por uma experiência particular de tradução simbólica de idéias e de teorias.? Mesmo que vivenciada inconscientemente, tal tradução já delimita uma experiência intelectual particular que deve ser explicitada para que a crítica social possa revelar sua pertinência discursiva. Os próprios princípios da tradução são delimitados por duas fontes, lembra Bruno Karsenti. De um lado, há que se reconhecer a existência de princípios que são sempre formulados a partir de fatos sociais concretamente pensados; de outro, alguns fatos apresentam-se como mais interessantes para revelar aqueles princípios da tradução, que outros fatos disponíveis (Karsenti, 1994, p. 93).

Desde que a criação intelectual se inscreve num mundo intersubjetivo, é inevitável que as traduções e as classificações de idéias obedeçam a certas particularidades fenomenais. Para Gregory Bateson, o fenômeno do contexto, assim como o da significação, define a separação entre a ciência na acepção clássica e a ciência que ele se propunha a fundar, a "ecologia do espírito" ou ecologia de idéias que permitiria compreender as razões pelas quais certos sistemas de idéias sobrevivem e outros não. E ele acrescenta que a exploração do conhecimento implica "a identificação de uma rede mais vasta e dispersa de índices ou pontos 
de referências, a partir dos quais se define um território científico novo" (Bateson, 1977, pp. 14-15). Entendemos que tal rede, no âmbito de nossa discussão, tem pelo menos quatro pontos de intersecção: o discurso no seu contexto original; o lugar do autor-tradutor e de sua modalidade expressiva própria; as idéias enraizadas, em moda e dominantes no campo intelectual do autor-tradutor; e o senso comum do contexto em observação.

O que se diz, ou não, a respeito de um autor ou de uma teoria, é resultado de uma presença perceptiva do intelectual-tradutor no seu mundo de idéias e no seu contexto sócio-histórico. Neste trabalho de contextualização das idéias há, inevitavelmente, um movimento de naturalização de certas narrativas, o que implica marginalização de outras idéias. O lugar de onde se pensa e se fala - lugar intelectual, científico, moral - delimita o campo de percepção do autor-tradutor, abrindo portas para o conhecimento e fechando outras. Tudo isso gera omissões aparentemente inexplicáveis. Ao mesmo tempo se naturalizam certas crenças intelectuais que, ao ganharem aura de verdade científica, inibem a apresentação e a discussão de outras narrativas sobre o tema.

\section{Contextualizando os estudos sobre o dom}

\section{O momento político}

David Le Breton comenta que as sociologias nascem em zona de turbulência, de falta de referência, de crise de instituições, "lá onde são eliminadas as antigas legitimidades" e onde há necessidade de "se dar significação à desordem aparente, de encontrar as lógicas sociais e culturais" (Le Breton, 2006, p. 11). Este comentário me parece apropriado para situar o contexto histórico que delimita o trabalho de sistematização, por Mauss, dos estudos sobre o dom, na década de vinte do século passado. Este era um contexto de turbulências sociais, políticas, mas também teóricas. Pois foi entre as duas grandes guerras que o mundo passou a conhecer a emancipação dos dois principais paradigmas do século XX, o individualista mercadológico e o holista-burocrático: o primeiro, assentado sobre o mercado, o segundo, sobre o Estado.

A redação do Ensaio sobre a dádiva, em 1924, não foi mero exercício intelectual, mas responde às inquietações dele sobre os rumos hesitantes do movimento bolchevique na Rússia, na tentativa de criar as condições para a emergência do socialismo real. Simpatizante inicialmente da revolução russa (Graeber, 2006), Mauss cedo compreendeu que as tentativas dos bolcheviques de eliminar a economia de mercado, interpretada como um empecilho para o projeto revolucionário, estava condenada ao fracasso. Caillé e Graeber (2002) destacam a preocupação que teria tomado conta deste intelectual socialista francês quando constatou que os revolucionários russos teriam cometido um equívoco ao tentar implantar o socialismo pela eliminação do mercado. As reflexões de Mauss nos anos de 1920 implicam, pois, certa reorientação dos estudos da escola sociológica francesa num contexto marcado por fortes turbulências políticas (Primeira Guerra Mundial e revolução bolchevique) e pelos ares inovadores da modernização urbana e dos valores libertários expressos nas lutas pelos direitos de cidadania, no plano micro, e de reorganização da sociedade mundial, no plano macro.

O drama vivido pela esquerda socialista em face dos impasses da revolução russa, em particular pela incapacidade deste movimento de eliminar a economia de mercado, desafiava os espíritos da época, levando Mauss a redefinir sua compreensão da sociedade, lembra D. Graeber (2006). Tal drama apontava para a necessidade de o pensamento crítico rever o lugar do mercado na modernidade, deixando de lado o viés maniqueísta das esquerdas (associação do mercado com o mal), para reinterpretá-lo como um mecanismo essencial às trocas nas sociedades complexas.

Além do contexto histórico que delimita as preocupações de Mauss, não podemos deixar de lembrar a influência de seu tio, Émile Durkheim, um crítico severo do utilitarismo econômico, conforme observamos nas críticas formuladas por ele no segundo prefácio da Divisão do trabalho social, quando propõe a necessidade de regulamentar a atividade econômica, pois esta, deixada a si mesma, traria grandes danos para a sociedade. Referindo-se ao propósito de seu livro, Durkheim lembra ter insistido várias vezes sobre o "estado 
de anomia jurídica e moral em que se encontra atualmente a vida econômica" e que o mundo econômico nos dá o triste espetáculo de desordens de todos os tipos, o que exige regulamentação e uma força moral que se faça respeitar. Até porque é falso o antagonismo "que se quis estabelecer com excessiva freqüência entre a autoridade da regra e a liberdade do indivíduo" (Durkheim, 2004a, pp. VI, VII, VIII). Embora o antiutilitarismo de Mauss tenha se voltado progressivamente para uma reflexão sobre os sentidos das práticas e das motivações da ação social, não se pode negar que a posição teórica e política do seu tio - contra a ação de desregulamentação do mercado sobre a ordem social -, tenha tido influência importante sobre sua trajetória.

A crítica ao individualismo mercantilista, já presente em Durkheim, de um lado, e a tentativa de encontrar saídas para o pensamento de esquerda e para o movimento associacionista, neste contexto de revisão do debate da escola francesa e de incerteza da geopolítica européia, de outro lado, são ingredientes que levaram Mauss a rever progressivamente as teses socialistas, visto que estas demonstravam insuficiência para a crítica do utilitarismo econômico dominante.

\section{O momento intelectual}

A sistematização da teoria do dom estabelece uma continuidade inegável com relação à produção sociológica de Durkheim e à parceria deste com Mauss. Do ponto de vista conceitual, a teoria do dom situa-se, no nosso entender, no desdobramento final das três tópicas de Durkheim: a primeira tem a ver com a compreensão do fato social numa perspectiva funcional e histórica, que encontramos na Divisão do trabalbo social; a segunda, que remete às representações coletivas dos fatos sociais, está presente em Formas elementares da vida religiosa, que redefine o fato social a partir das crenças e representações coletivas. A terceira, apenas esboçada, mas de grande relevância, diz respeito ao seu interesse de articular a discussão mais geral das representações coletivas com a preocupação do pragmatismo de associar as idéias às coisas e à experiência, de ligar o pensamento à vida, o que implica numa crítica importante ao racionalismo que foi captada acertadamente por Durkheim.

A primeira e a segunda tópicas são bastante conhecidas. Por isso, vamos nos dedicar a avançar algumas considerações sobre a terceira.

Esta sugere uma nova releitura do fato social, a partir do esforço de Durkheim de articular as representações coletivas com as experiências dos indivíduos em interação na vida cotidiana, esforço que o leva a oferecer um curso sobre Sociologia e Pragmatismo, entre dezembro de 1913 e maio de 1914 (Durkheim, 2004b). O caráter antiutilitarista do sistema do dom tem como importante referência a renovação da crítica intelectual durkheimiana presente neste curso. O resgate dos registros desta terceira tópica, que Mauss definiu como a coroação da filosofia de Durkheim, foi possível devido ao esforço do próprio Mauss de recuperar as anotações de aulas feitas pelos ex-alunos que sobreviveram à guerra. Tais anotações são a base do livro Pragmatisme et sociologie (2004b), que reúne anotações de sala de aula de alunos do autor, reunidas por Durkheim no pós-guerra.

Neste curso, ele trata da relação entre a escola pragmatista norte-americana - representada por figuras como Peirce, James, Dewey e Mead - e a sociologia, buscando articular teoricamente suas reflexões sobre as representações coletivas, com as teses, aparentemente opostas, do pragmatismo social norte-americano, que tentava associar a produção intelectual sobre a verdade aos determinantes psicosociais e não utilitários das práticas interativas. Para o fundador da sociologia francesa, haveria no pragmatismo, em particular nas teorias mais sociológicas de C. Peirce e G. Mead, um sentido de vida e de ação individual que seria muito importante para os estudos da sociedade. De fato, há nesses autores uma preocupação evidente de pesquisar os fundamentos da vontade coletiva sem cair no excesso de formalização dos sistemas sociais, nem nos casuísmos racionalistas das teorias individualistas do contrato social. Se considerarmos, por exemplo, John Dewey, encontramos nele, lembra Honneth, uma teoria da cooperação reflexiva que é fundamental para se pensar a democracia e a associação nos dias atuais, e entender a democracia como uma forma reflexiva de cooperação comunitária que supera os limites 
das disputas entre republicanismo e procedimentalismo (Honneth, 2002, p. 267). Esta é uma pista importante para se explorar a relação entre dom, associação e democracia.

Esta terceira fase da obra de Durkheim foi interrompida devido a alguns fatos: a eclosão da Primeira Guerra Mundial, a morte de seu filho André, na guerra, e o falecimento do próprio Durkheim, em 1917, por não ter suportado a perda do filho. Mas esta fase constitui, no nosso entender, uma fonte de inspiração decisiva para Mauss conceber a tese do "fato social total", que se funda, ao mesmo tempo, nas crenças coletivas e nas experiências concretas dos atores sociais, e que permite completar o desenho da filosofia moral libertária, inicialmente proposta por Durkheim.

\section{O dom: do estruturalismo para o pós-estruturalismo}

Essas observações são cruciais para a virada epistemológica que enfatiza uma leitura não-estruturalista do dom, mas que não recusa de algum modo a importância do estruturalismo. Não se trata de menosprezar o conhecimento científico para valorizar no seu lugar o saber comum e cotidiano, como o propõem alguns pós-estruturalistas. Trata-se de preservar a possibilidade do método científico sem desconsiderar a importância do individualismo contemporâneo em refazer as narrativas e o próprio método. Nessa perspectiva é de se perguntar: até que ponto o dom se constitui num sistema universal válido em todas as circunstâncias ou conhece ele igualmente as vicissitudes da relatividade da tradução que põe em suspeita a objetividade do método lingüístico?

Analisando-se o privilégio adquirido pela antropologia estrutural neste trabalho de difusão do dom no Brasil - e, igualmente, o esquecimento de outras leituras possíveis desta contribuição de Mauss -, somos levados a concordar que as dificuldades da tradução também se fazem presentes neste caso. Por isso somos favoráveis a que se respeite a pluralidade de leituras do pensamento crítico para que se possa comparar e analisar as diferenças e as proximidades de interpretações até que se chegue a alguns consensos. Ou seja, a divulgação dos estudos sobre a dádiva não pode ser limitada a um modo único e verdadeiro que teria como autor-tradutor privilegiado, ao menos no Brasil, Claude Lévi-Strauss, e como disciplina central a antropologia estrutural.

Nesse texto queremos demonstrar, ao contrário, que são diversas as modalidades de leitura da obra deste autor e, em especial, do Ensaio sobre a dádiva, de 1924 (Mauss, 2003), que Georges Gurvitch, na apresentação que fez da primeira edição de Sociologie et anthropologie, define como uma das obras-primas da sociologia francesa. No caso da diversificada obra de Mauss - autor com formação em filosofia, filologia, história, etnologia, sociologia e antropologia -, é possível relacionar diversas possibilidades de releituras desse ensaio. Guardando esta perspectiva, Marcel Fournier, importante biógrafo de Mauss, organizou recentemente, na revista Sociologie et Sociétés, uma coletânea intitulada "Présences de Marcel Mauss" (Fournier e Marcel, 2004), na qual relaciona autores que receberam influências diversificadas de Mauss, como Pierre Bourdieu, Jean-Pierre Vernant e Maurice Agulhon. Para os que propõem que a teoria do dom possui implicações teóricas, morais e políticas mais amplas que aquelas da antropologia estrutural - tese que defendemos neste texto -, há outros interlocutores importantes a assinalar, como Mary Douglas, no pensamento antropológico anglo-saxão, Claude Lefort e Alain Caillé, na filosofia política francesa, Maurice Godelier, na antropologia comparada, ou Jacques Godbout, na sociologia.

Nessa perspectiva, entende-se que a força do estruturalismo antropológico na mediação do trabalho de tradução dos estudos sobre o dom no Brasil tenha contribuído de algum modo para deixar "invisível" uma importante leitura não-estruturalista que na França subsistiu de modo mais tímido durante a fase hegemônica do estruturalismo e que foi retomada com intensidade a partir da década de 1980 quando a hegemonia do estruturalismo passou a ser questionada. Tal releitura denominada por alguns de pós-estruturalista significou a abertura dos estudos sobre o dom a partir de novos contextos, em particular aquele do individualismo contemporâneo que leva necessariamente a se pensar "os dispositivos democráticos de outros mundos possíveis" (Corcuff, 2006, p. 86). Tal individualismo, diferente daquele narcisista que reforça o egoísmo e a separação, permite redefinir a 
obrigação do dom - que tem um peso importante na leitura tradicional do tema e, em particular, naquele do estruturalismo - a partir da liberdade do indivíduo de aceitar, ou não, os atos de doar, de receber e de retribuir.

Há mais de duas décadas, vêm crescendo progressivamente as pesquisas, as teses, os cursos e os encontros que se apóiam numa outra compreensão do dom, que ultrapassa a leitura antropológica restrita oferecida pelo estruturalismo para incorporar percepções diferenciadas advindas de uma perspectiva pós-estruturalista e interdisciplinar. Esta releitura foi fornecida pelo cruzamento de disciplinas como a sociologia, a política e a filosofia, e a própria antropologia, que se libertou progressivamente do esquema teórico rígido do estruturalismo, o qual desvalorizava tanto a liberdade do indivíduo e dos grupos sociais como a importância do senso comum na invenção de modalidades diversificadas e plurais de organização do pacto cultural e social.

O debate que se segue ao estruturalismo tem contribuído para retomar o espírito humanista e libertário da escola francesa de sociologia, em particular os estudos sobre o dom ${ }^{10}$ com perspectivas importantes para a renovação das ciências sociais. A importância que estamos dando às condições de tradução de contextualização sócio-histórica dos estudos sobre o tema, no Brasil, tem uma significação particular no que diz respeito ao lugar desta teoria na formulação de um novo movimento teórico.

Os estudos sobre o dom na perspectiva pósestruturalista permitem avançar no campo das ciências sociais a crítica teórica de Merleau-Ponty ao dualismo cartesiano e resgatar o valor da intersubjetividade pela demonstração de que existe uma estreita ligação entre dádiva e simbolismo. Na origem, lembra Caillé, o símbolo é o próprio signo da aliança, e esta apenas é contraída pela dádiva. Não podemos apreender a dádiva abstratamente, "mas apenas a partir do que se passa entre os atores, a partir do que os une ao separá-los, campo de intermediação que o fenômeno do simbolismo institui e no qual consiste" (Caillé, 1998, p. 31). Na concepção do símbolo e do simbolismo não existe "nem indivíduo nem sociedade, mas somente um sistema de signos que mediatiza as relações que cada um mantém com cada um, construindo num mesmo movimento a socialização dos indivíduos e sua unificação em um grupo" (Karsenti, 1994, p. 87). ${ }^{11}$ Ora, se o símbolo e o dom são fenômenos que se complementam - quando não se completam no processo concreto de formulação de alianças geradoras do social -, então devemos reconhecer que o debate pós-estruturalista do dom tem importância estratégica para um pensamento crítico e plural e, como defenderemos neste artigo, para se pensar a emancipação de uma ciência moral e humanista.

\section{O dom, o pós-estruturalismo e o individualismo contemporâneo}

De certo modo, Mauss antecipou esta abertura dos estudos não-estruturalistas sobre o dom na sua fase de maturidade, em um texto intitulado "Fato social e formação do caráter", que preparou para apresentação no Seminário Internacional de Ciências Etnológicas e Antropológicas, ocorrido na cidade de Copenhague, em 1938. Neste pequeno texto, há comentários reveladores a respeito do individualismo moderno que ele, então, passava a considerar fundamental para se pensar a modernidade. Diz ele que "é em oposição à vida coletiva que o indivíduo - o ser - de pura consciência e liberdade, se criou na vida". Para ele, em outra passagem, o indivíduo tornou-se, nas sociedades modernas, sujeito e objeto, agente responsável da vida social: "Agora, o indivíduo é a fonte da mudança social. Ele sempre o foi, mas não sabia" (Mauss, 2004, p. 140). ${ }^{12}$ Esta intuição de Mauss é confirmada por M. Godelier, para quem nas sociedades modernas três coisas se modificaram fundamentalmente: a relação dos indivíduos com a sexualidade, o lugar dos homens e das mulheres na sociedade (e, portanto, a relação entre sexos) e o lugar das crianças (Godelier, 2004, p. 565). Esta emergência do individualismo reflexivo moderno não ficou indiferente a Mauss, como vimos ao lembrar suas notas para o congresso de Copenhague.

Existem, então, outros autores de formações diversas na antropologia e na etnologia, mas, igualmente, na sociologia, na economia, na história e na filosofia que, sem negar a importância de Mauss para a fundação da antropologia estrutural, recusam-se a aceitar o reducionismo discipli- 
nar que nega o valor da liberdade individual, em contraste com a própria posição de Mauss. Eles sustentam, em conjunto, que Marcel Mauss tem uma contribuição bem mais geral para a teoria crítica contemporânea, a qual não tem sido devidamente ressaltada. Esta contribuição, acrescentamos, tem uma relevância não apenas acadêmica, mas, sobretudo, política, pelo que significa como referência para uma crítica sistemática e poderosa do utilitarismo econômico, a partir dos horizontes abertos pelo pós-estruturalismo.

Aqui, há, de fato, uma distância importante entre as expectativas nutridas por antropólogos e sociólogos com relação aos usos do dom. Se para os antropólogos na linha do estruturalismo a presença de sistemas fixos de trocas é decisiva para explicar as sociedades tradicionais, para os sociólogos, simpatizantes de uma abordagem pós-estruturalista, interessa na teoria do dom outra coisa, a saber: como a liberdade do indivíduo moderno subverte os sistemas de obrigação estabelecidos, para criar novos sistemas de reciprocidades ambivalentes e abertos. Por exemplo, o dom entre anônimos, como a doação de sangue, é um fenômeno típico dos tempos modernos, assim como o trabalho voluntário junto a desconhecidos (o que não acontece em sistemas de troca tradicionais, nos quais a proximidade sanguínea e étnica são fatores determinantes do dom), ou as trocas horizontais, chamadas de dádiva-partilha, entre homens e mulheres.

Para a sociologia e para a filosofia política contemporâneas, a atualidade crítica do dom se faz, portanto, a partir da relevância da reciprocidade aberta para se compreender a dinâmica e a complexidade das trocas nas sociedades dos indivíduos, trocas que são sempre determinadas por ambivalências constituídas entre os motivos da liberdade e da obrigação, do interesse e do "desinteressamento" (Caillé, 1998, 2002b, 2006). Em suma, há no próprio Ensaio..., e em outros textos do Mauss, uma leitura teórica alternativa menos voltada à explicação das sociedades tradicionais do que correlacionada com a modernidade. Afinal, como afirma Mauss no final de seu texto preparado para o Congresso de Copenhague, não se trata de cair num viés romântico de fazer o culto dos heróis, "mas de despertar nos homens o sentido do que eles são para a sociedade o sentido de mudanças sociais na sociedade que eles de- vem conservar cuidadosamente e (querer) decididamente" (Mauss, 2004, p. 140). Enfim, esta outra leitura - pós-estruturalista ou não estruturalista, dependendo do ângulo de observação - apenas foi realçada, nos inícios dos anos de 1980, no contexto de enfraquecimento das teses estruturalistas e do surgimento de "novas sociologias", que resgatam a crítica antiutilitarista contida no dom e sua relevância para a consolidação da crítica moral humanista, presente no espírito socialista e associacionista de Durkheim e Mauss.

Temos, então, duas explicações válidas da teoria do dom. Uma diz respeito, como já foi assinalado, à fama adquirida pela antropologia estrutural e pela associação do dom com o método lingüístico estrutural que permitiria apreender os sistemas separados da realidade, determinando as regras existentes entre tais sistemas. A outra tem a ver com o modo como Mauss busca, intencionalmente, com base nos estudos das sociedades arcaicas, desenvolver as linhas gerais de uma reflexão própria às sociedades modernas, que tem dois pontos de destaque: uma crítica da filosofia utilitarista e da teoria econômica dominantes nas sociedades contemporâneas, esboçada na conclusão de seu ensaio sobre o dom; e a valorização da liberdade de interação dos indivíduos na organização da vida social. Esta crítica é realizada indiretamente, a partir de uma etnografia que se inspira nos sistemas de trocas nas sociedades arcaicas para deduzir que sua universalidade atravessaria as sociedades modernas. Mauss sugere que o fenômeno do dom continua sendo fundamental para explicar a aliança na atualidade, revelando, claramente, sua intenção de demonstrar esta tese quando afirma que "é possível estender essas observações à nossas sociedades" (Mauss, 2003, p. 294). Este segundo aspecto leva certos autores a posicionar Mauss ao lado de Simmel, como fundadores do interacionismo crítico que defende a hipótese de que a sociedade se funda a partir das relações humanas (Papilloud, 2004; Caillé, 2002b).

\section{Resgatando o estruturalismo pelo social}

Podemos nos perguntar se o destaque dado a Lévi-Strauss como autor-tradutor privilegiado das idéias de Mauss - em larga medida, justificado pela 
sua relevância para a antropologia contemporânea - é, de fato, o problema central das divergências acadêmicas em torno do tema. Nossa opinião é que esta disputa é periférica e que tanto os antropólogos lévi-straussianos como seus críticos têm razão.

Lévi-Strauss utilizou com muita competência a revelação de Mauss sobre as trocas simbólicas e generalizadas para propor teses interessantes, entre elas destaca-se a definição da família como fa-to social. Pois, ao resgatar o conceito maussiano de aliança para explicar a constituição do parentesco a partir do pacto social, ele rompe com a visão biológica de família, permitindo nova compreensão do fenômeno social. Na perspectiva de LéviStrauss, as relações de parentesco não derivam de grupos familiares isolados, mas se constituem por códigos, configurando um sistema de comunicação cultural e social, melhor dizendo lingüístico, como se observa na leitura de sua descrição minuciosa do parentesco (Lévi-Strauss, 1982).

Isto não elimina, porém, uma questão central: os limites claros do campo de investigação científica do pai do estruturalismo para a explicação da sociedade moderna, como já foi lembrado. Pois Lévi-Strauss desenvolveu sua teoria das trocas a partir não do fenômeno urbano - como propõe Mauss na conclusão do Ensaio... - mas da organização das sociedades tradicionais, entre elas as tribos nambiquaras, de Mato Grosso (que ele visitou algumas vezes quando esteve no Brasil como professor da Universidade de São Paulo). Ou seja, as conclusões da antropologia estrutural - como, por exemplo, a do tabu do incesto -, não foram pensadas em contextos urbanos, mas a partir de grupos sociais organizados de forma tradicional, com influência decisiva do fato religioso.

Em larga medida, as observações de LéviStrauss sobre esses grupos sociais tradicionais confirmam as observações de Mauss a respeito de haver uma obrigatoriedade fundadora de trocas e contratos feitos sob a forma de presentes, em sociedades como aquelas da Escandinávia, nas quais, apesar de aparentemente voluntárias, as trocas eram obrigatórias. No desenvolvimento deste raciocínio, já na introdução do Ensaio..., Mauss propõe que, de todos os temas complexos e dessa multiplicidade de coisas em movimento, ele gostaria de analisar apenas um dos traços que conside- rava profundo, mas isolado: "o caráter voluntário por assim dizer, aparentemente livre e gratuito, e, no entanto, obrigatório e interessado dessas prestações" (Mauss, 2003, pp. 187-188). Nessa perspectiva, é correta a ênfase que Lévi-Strauss dá ao valor da obrigação - sintetizado na sua tese sobre o tabu do incesto - que ele elaborou a partir da investigação do casamento prescrito entre primos cruzados (um primo se proíbe de casar com a irmã do primo na expectativa de que este renuncie igualmente a casar e possuir sua irmã). Mas, é apenas válida no que diz respeito a este tipo de sociedade, em que a moral coletiva e religiosa se impõe claramente sobre as condutas dos membros do grupo, não servindo para generalizações. Pois esta teoria da aliança, baseada no casamento prescrito, não pode ser estendida à sociedade moderna individualista, em que a constituição da parentela passa a ser largamente influenciada pela ação individual.

Na verdade, a dádiva contém em si não apenas os fundamentos teóricos para os estudos sobre o simbolismo na contemporaneidade (assunto que voltaremos a tratar adiante), e que marcou os estudos antropológicos no século XX, mas, igualmente, uma crítica perspicaz do utilitarismo econômico e mercadológico a partir de um conceito de "fato social total", cuja ambição deixa revelar os traços de uma ciência moral transdisciplinar. ${ }^{13}$ No Ensaio sobre a dádiva, a contribuição de Mauss para o debate antiutilitarista aparece no modo como ele demonstra estarem as idéias de mercado, de aliança, de trabalho, de contrato e de solidariedade irremediavelmente ligadas a certas fundamentações de caráter moral.

A fundação do M.A.U.S.S. - Movimento Antiutilitarista nas Ciências Sociais -, na França, em 1981, expressa adequadamente tal reação teórica, voltada para o resgate do legado teórico da escola francesa de sociologia e de seu valor para sistematizar uma crítica mais articulada do economicismo. ${ }^{14}$ A releitura da obra de Mauss por este movimento tem permitido retomar e ampliar o valor de sua crítica teórica e demonstrar sua importância para reorganizar os campos disciplinares nas ciências sociais contemporâneas. Este novo trabalho de tradução ocorreu num momento muito especial, o da crise do paradigma estruturalista nas ciências sociais a partir da "virada lingüística" dos fins dos anos de 1970 (Dosse, 1997) e, também, o de ex- 
pansão de um intercâmbio intelectual muito rico entre a escola francesa e a escola anglo-saxônica. Este intercâmbio revela-se com particular interesse no interior do M.A.U.S.S., pois havia uma tentativa de articular a dádiva com a tradição pragmática norte-americana e com as escolas interacionistas (Caillé, 2002b; Chanial, 2001), retomando, de certa forma, o trajeto interrompido pelo pai da sociologia francesa.

Nas páginas seguintes, voltaremos à teoria maussiana à luz desta interpretação pós-estruturalista e contextualizada, de modo a avaliarmos sua abrangência conceitual e sua contribuição para a renovação do campo intelectual.

\section{Elementos da teoria do dom}

\section{A noção de simbolismo}

O ciclo do dom confunde-se com o ciclo da vida ao realçar a relação orgânica entre qualidade do vínculo e da aliança e finalidade da vida humana. Trata-se de uma questão de interesse moral e que tem implicações políticas na medida em que, como nos lembra J. Baechler, "um fim é a solução de um problema de sobrevivência posto à espécie pela sua natureza, uma solução que põe de imediato um novo problema: o que fazer para que a solução se torne real?" (Baechler, 2002, p. 63). O ciclo do dom permite compreender que a qualidade da relação entre o ser humano e a natureza em geral depende de uma questão moral: a capacidade de correr o risco de se relacionar com outros, com vistas à produção do mundo pelo trabalho, pela política, pela honra ou dignidade, mas, sobretudo, pelo interesse coletivo de se fazer alianças com vistas a tornar perene o movimento fluido das instituições sociais e culturais. ${ }^{15}$

Tal risco é devidamente assinalado por Mauss nas conclusões do Ensaio sobre a dádiva, ao propor que, de uma ponta à outra da evolução humana, não há duas sabedorias: "Que adotemos então como princípio de nossa vida o que sempre foi um princípio e sempre o será: sair de si, dar, de maneira livre e obrigatória; não há risco de nos enganarmos" (Mauss, 2003, p. 301). A maturação do ciclo do dom, esclarece, favorece o entendimento, a amizade, a aliança e a honra, do mesmo modo que, no lado contrário, sua interrupção é motivo para a inimizade, a desonra e a guerra. Como teoria relacional, o dom permite enfoques originais e múltiplas interpretações da realidade, inclusive a de repensar a produção econômica e o trabalho social não apenas a partir da exploração e do conflito, mas incorporando indicadores de bem-estar e de "vida boa".

Ao ampliar a compreensão da sociedade pela introdução do simbolismo, ${ }^{16}$ Mauss superou a dicotomia que tinha aprisionado Durkheim entre o sagrado e o profano (Caillé, 1998) e fez avançar a compreensão da sociedade superando outra dicotomia clássica da sociologia, aquela entre agência e estrutura. Mediante a concepção do simbolismo, diz Karsenti, percebe-se "que a oposição entre individual e coletivo perde literalmente toda pertinência. Ou melhor, temos que aceitar que esta distinção corresponde apenas a variações diferenciadas de um simbolismo único, característico de uma sociedade determinada" (Karsenti, 1994, p. 91). Enfim, neste trabalho de desconstrução de um mito de "economia natural" que teria existido, desde sempre, a partir da presença de um homo oeconomicus agindo motivado por seus interesses individuais e egoístas, vários autores concordam (Karsenti, 1994; Godbout, 1998a; Caillé, 2000b; Martins, 2005) que o mais importante na crítica de Mauss ao utilitarismo foi demonstrar que os bens que circulam na sociedade não são apenas materiais, mas, sobretudo, simbólicos. Diz Godbout que no ato de doação de algo a alguém, não é apenas a coisa que é dada, mas, também, a intenção (Godbout, 2000) ou o "hau", o "espírito da coisa" (Mauss, 1999, p. 161). Assim, na organização da prática social, há sempre dois bens em circulação: um material, a coisa dada, um simbólico, a intenção oferecida.

Merleau-Ponty entendeu claramente a importância de Mauss para as ciências sociais ao afirmar que sem negar os princípios da escola francesa ou os de Durkheim, ele conseguiu superar o erro de situar o observador fora do objeto observado, erro que impediria a "penetração paciente do objeto, a comunicação com ele" (Merleau-Ponty, 1960, p. 126). Mas esta penetração no fenômeno apenas pode ocorrer, explica o autor, se entendermos que o fato social não é uma realidade bruta, mas "um sistema eficaz de símbolos ou uma rede de valores simbólicos que se insere no mais profundo dos 
indivíduos", levando-nos a compreender que não temos que escolher entre indivíduo e sociedade, pois são tudo totalidades ou conjuntos articulados (Idem, p. 125).

Por conseguinte, enfatiza Merleau-Ponty, Mauss, ao conceber o social como um simbolismo, permitiu-se os meios de respeitar a realidade do indivíduo, aquela do social e a variedade de culturas, sem tornar umas e outras impermeáveis entre si. "Uma razão ampliada deve ser capaz de penetrar até o irracional da magia e do dom" (Idem, p. 126).

\section{O fato social total}

A simpatia de Mauss para com o movimento associacionista do início do século XX, na França, levou-o a refletir em profundidade sobre os motivos variados da associação humana. Segundo ele, tais motivos não podem ser restringidos a certos determinantes particulares - econômicos, políticos e/ou culturais -, visto que tudo tem relevância para a constituição do vínculo social, sendo a sociedade um "fato social total".

A crítica ao utilitarismo mercantil, de um lado, o resgate da dimensão moral da vida social, de outro, levaram Mauss a rever e ampliar a noção de fato social de Durkheim. Para ele, a sociedade seria um "fato social total" e no interior do conjunto de prestações e contraprestações que definem a vida social em geral, a atividade econômica e mercantil seria apenas um aspecto particular deste conjunto, limitando-se pelo caráter dos rituais e das obrigações coletivas. A esse respeito, esclarece Karsenti que o dom permite revelar os comportamentos de homens concretos e não um conjunto de regras jurídicas ou morais definidas abstratamente. Nesse sentido, complementa ele, o fato social total, longe de indicar uma generalidade desencarnada, "emana da descrição de uma realidade constituída de experiências comuns que manifestam a vida do grupo como grupo: "O completo, mediante um singular desvio, se identifica ao concreto, concebido sob a forma da expressão viva de um grupo social considerado na sua globalidade" (Karsenti, 1994, p. 45).

Neste esforço de entender as razões nãoeconômicas das trocas sociais, Mauss foi levado a rever a premissa durkheimiana do fato social, reapresentando-o como "fato social total". Esta revisão teórica aponta, portanto, para um acontecimento inédito das ciências sociais, que foi produzido entre Durkheim e Mauss, a saber, a invenção do simbolismo. Os estudos sobre as significações subjetivas das trocas, que o levam a valorizar a idéia de totalidade, foram sistematizados a partir das revisões feitas por Mauss das análises durkheimianas do sagrado, da religião e das representações coletivas, como o demonstra Camile Tarot (1999). A compreensão da sociedade como fato social total permitiu a Mauss superar as dualidades conceituais presentes no pensamento de seu tio, Émile, articulando de modo dialógico categorias aparentemente opostas, como o macro e o micro, o subjetivo e o objetivo, o individual e o grupal, o sagrado e o profano, o cultural e o social, a práxis e a teoria, o unidisciplinar e o multidisciplinar. ${ }^{17}$

A sistematização dos estudos sobre a dádiva levou Mauss, de certo modo, a uma ruptura parcial com o esquema teórico de Durkheim. Enquanto este via a obrigação como a condição central e incondicional da moral social, Mauss entendia que o sistema moral conhecia certa flexibilização, resultante da pluralidade de determinações. Assim, embora considere o dom uma obrigação em última instância, ele reconhece que, na prática, há uma ambivalência constitutiva do dom entre a obrigação e a liberdade, entre o material e o simbólico e que se insinuam no movimento de produção do fato social que é total.

A atualidade da contribuição de Mauss para as ciências sociais pode ser, assim, sintetizada em dois pontos fundamentais: a definição da sociedade como um fato social total, permitindo articular adequadamente aquelas dicotomias tradicionais da sociologia já referidas, e a introdução do simbolismo como fundamento último das trocas entre pessoas morais. Trata-se de uma contribuição de importância paralela àquela do sujeito do inconsciente de S. Freud, com a diferença de que, em Mauss, a noção de pessoa moral não se limita às injunções de crenças coletivas, como em Durkheim, nem ao cognitivismo individualista, da psicologia experimental. A pessoa moral, em Mauss, supera ambas as posições pela ênfase sobre o valor da relação na constituição da sociedade.

A proposição do dom como base de uma ciência moral e humanista ${ }^{18}$ explica-se pelo seu re- 
conhecimento como fenômeno de caráter relacional e paradoxal que articula diferentes planos do conhecimento, como aqueles formados pelos pares do objetivo e do subjetivo, do micro e do macro, do profano e do sagrado, do individual e do social. Trata-se de um sistema de conhecimento, ao um só tempo, simples e complexo. Simples, na medida em que busca explicar a realidade, inicialmente, não a partir de estruturas regulamentadas, mas, diversamente, a partir de um sistema infor$\mathrm{mal}$, aquele das trocas diretas entre indivíduos e grupos no plano da vida cotidiana. Complexo, porque ambiciona ultrapassar o campo restrito do plano microssociológico para demonstrar que as regras paradoxais que delimitam as trocas da vida cotidiana se reproduzem igualmente na esfera macrossociológica dos sistemas formais, de forma sub-reptícia certamente, mas decisiva para selar por meio da confiança a validade dos contratos jurídicos e administrativos.

Ele teve sucesso na empreitada teórica do "fato social total" - que é uma categoria abrangente do ponto de vista teórico e disciplinar -, quando entendeu que a aliança nasce de uma expressividade coletiva e compartilhada - gestos, rituais, trocas, mortes etc. - que envolve todos os membros do grupo, acionando, para isso, os recursos afetivos, cognitivos, materiais e espirituais existentes na comunidade. Do mesmo modo, percebeu que a construção da aliança entre pessoas morais exige que o conjunto de recursos visíveis e invisíveis (materiais e simbólicos) disponíveis na tradição e na memória circule permanentemente, envolvendo todos os participantes em ações recíprocas de doações, recebimentos e retribuições. A recusa de participar de tais atividades - festas, rituais, serviços gratuitos, trabalhos conjuntos etc. - em geral é percebida pela comunidade como um sinal negativo, como se fosse uma manifestação de descaso ou mesmo de inimizade.

Enfim, a idéia de "fato social total" pressupõe a presença de sistemas de reciprocidades das atividades humanas, sustentados por um simbolismo generalizado em todos os planos da vida, começando com mais intensidade afetiva e menos regulação cognitiva no plano do cotidiano (do indivíduo, da família, dos amigos etc.) e se estendendo com menos intensidade afetiva e mais regulação cognitiva para as estruturas formais (da economia, da política, da religião, da ciência etc.). Isto é, tudo o que se troca - tudo o que se dá, que se recebe ou que se retribui - é carregado de sentidos duplos: as palavras são pronunciadas com gestos expressivos, os presentes são dados com boas ou más intenções, as ordens são proferidas com sentimentos de orgulho ou de baixo-estima, as mercadorias são vendidas com imagens de sedução ou de repulsão. Pela associação do dom com o simbolismo generalizado, Mauss conseguiu demonstrar que as coisas materiais ofertadas, as hospitalidades dadas e os serviços prestados são plenos de significações que, num lado, favorecem a aliança e o vínculo e, no lado contrário, a inimizade.

Compreendido como "fato social total", o sistema do dom deixa de constituir uma teoria do domínio particular de determinada disciplina - seja ela a antropologia, a etnologia, a história, a sociologia, a política, a lingüística ou outra qualquer -, para aparecer como o fundamento de uma ciência moral antiutilitarista poderosa, que oferece os recursos conceituais necessários à crítica do pensamento mercantilista hegemônico e à revalorização do indivíduo dentro dos sistemas de obrigações coletivas. A força crítica do dom está no seu caráter paradoxal, permitindo compreender a sociedade como um conjunto de fatores diversos que se entrecruzam, mas que não se submetem funcionalmente a uma determinação qualquer, seja ela a religião - nas sociedades tradicionais -, ou a economia de mercado - nas sociedades modernas. O reconhecimento do paradoxo do dom explica-se, por outro lado, pela sua possibilidade de demonstrar, a partir do simbolismo, que a realidade social e cultural é fabricada por significações compartilhadas por indivíduos e grupos sociais, que sustentam a invenção do mundo em vários planos: no micro e no macro, no individual e no social, no sagrado e no profano, assim como, podemos acrescentar, no masculino e no feminino, no similar e no diverso.

Do mesmo modo, ao permitir compreender que essas trocas entre indivíduos, grupos e nações são, em geral, incertas, indeterminadas e assimétricas, o sistema do dom contribui para que se entenda que a regra de equivalência típica da economia de mercado - um bem dado implica em um bem pago - não é uma regra geral, como propõem os doutrinadores liberais e utilitaristas, mas a ex- 
ceção. Analisando a sociedade a partir do "fato social total", percebe-se, diferentemente, que grande parte das trocas segue uma regra assimétrica que se estende no tempo, gerando um endividamento simbólico coletivo dos membros da coletividade e expresso em regras, rituais, proibições e permissões. Certamente o reconhecimento da existência de trocas assimétricas não significa que estamos na ordem da democracia. Ao contrário, inúmeras sociedades tradicionais e mesmo modernas instituem sistemas de dominação a partir de assimetrias, como vemos no Brasil, por exemplo, a partir da instituição do clientelismo.

Mas, o simples reconhecimento da pluralidade de lógicas de organização do imaginário sócio-histórico e das práticas concretas, sejam elas simétricas ou assimétricas, é fundamental para se desnaturalizar a ideologia mercantilista e utilitarista que se propõe a aparecer como a única e legítima lógica de organização da vida moderna. Tal reconhecimento da diversidade é fundamental para se entender que, por trás do fetichismo da troca econômica simétrica, que está na base da lógica mercantil e cujo lema é trabalhar para consumir e acumular, há um desejo - assimétrico - bem mais amplo de compartilhar a vida, pois esta não pode ser vivida individualmente, mas apenas coletivamente. Tal consciência coletiva implícita é a base de uma ordem moral geral ligada ao anseio de preservação da sociedade e, em última instância, do ser humano, que é o motivo primeiro e último da constituição do vínculo social, da aliança e da política solidária.

$\mathrm{Na}$ verdade, o "rochedo no qual se assenta a vida social", como lembra Mauss na conclusão do Ensaio..., apenas é detectado quando entendemos que os bens que circulam no interior da sociedade são sempre portadores de um duplo sentido, material e simbólico. A tese do fato social total surge, na obra de Mauss, quando ele compreende que todos os eventos possuem uma significação simbólica para a vida social. Ao assim proceder, ele aprofunda a tese de Durkheim acerca da existência de uma obrigação social que sobredetermina a liberdade individual. Mas, ao mesmo tempo, o autor entende que as regras podem ser transgredidas ou negadas, pela vivência da liberdade, fazendo do que era paz, guerra, e vice-versa.

Mauss faz este aprofundamento ao introduzir uma compreensão simbólica da prática social não redutível apenas aos aspectos materiais ou aos valores utilitaristas baseados nos cálculos, nas necessidades e nas preferências. Pela valorização do simbólico, ele concluiu que tudo na sociedade é importante para esclarecer sua origem e funcionamento, sendo de particular relevância aqueles fatos que consideramos banais e irrisórios, como os risos, os gestos, as falas, os rituais, as danças, além, é claro, dos serviços e dos bens materiais (Mauss, 2003, p. 191).

\section{O dom e o interacionismo crítico}

\section{Dom e compreensão}

Como é possível a sociedade? Com esta pergunta C. Papilloud abre seu texto sobre uma reflexão comparativa entre Mauss e Simmel, para defender a tese de que esses dois autores são os reais precursores de uma abordagem inédita da relação humana, que pode ser definida como interacionismo crítico. Para Papilloud, a conversão de Maus para as teses interacionistas significou certo distanciamento de Durkheim, o que ficou evidente quando Mauss e Paul Falconnet escreveram o texto "Sociologia" para a Grande enciclopédia, no qual afirmam que o social se reconhece "pela presença de suas ações e reações, de suas interações" (Mauss, 1901, apud Papilloud, 2004, p. 61).

A. Caillé também propõe que o sistema da dádiva constitui uma abordagem interacionista, por excelência. Mas uma abordagem interacionista que não se limita ao plano microssociológico, pois considera com o mesmo valor a esfera macrossociológica. A compreensão do sistema do dom como uma modalidade particular do interacionismo teria ficado encoberta pela maneira como Lévi-Strauss inseriu o dom dentro dos estudos antropológicos (Caillé, 1998). Ao reduzir o dom a um sistema de troca relativamente rígido e próprio de sociedades tradicionais, a antropologia estrutural teria dificultado que viesse à tona a contribuição fundamental de Mauss para as ciências sociais e para o entendimento do dom como fato político, interativo e dinâmico.

É necessário, assim, romper o véu que isolava o dom dentro das ciências sociais (e da filosofia moral, acrescentamos), o qual induzia os pesquisadores a vê-lo como um fenômeno de interesse 
meramente antropológico e estrutural, com pouca relevância para outras disciplinas, sobretudo para aquelas relacionadas com o interacionismo. Devese notar que há diferentes escolas interacionistas, que não se situam apenas nos Estados Unidos e que se enraízam historicamente em outros países. Nesse sentido, Caillé lembra que, tal como os interacionismos de Simmel e de Elias, aquele de inspiração maussiana se diferencia do norte-americano por algumas razões. Em primeiro lugar, a excessiva ênfase dos estudiosos norte-americanos no plano microssociológico - no chamado "face a face". No caso do interacionismo em Mauss, diferentemente, "não somente é o conjunto das interações entre as pessoas que ele tende a considerar, na escala da sociedade no seu todo, mas também as relações das pessoas com os objetos, com as coerções materiais, em suma, com a morfologia social". Desse modo, conclui Caillé, temos aqui uma espécie de "interacionismo generalizado", que tem mais a ver com a sociologia histórica comparativa weberiana e com o marxismo do que com a psicologia social (base do interacionismo norte-americano) (Caillé, 2002b, p. 247).

Nesta tentativa de enquadramento da teoria do dom como uma abordagem interacionista aberta a uma compreensão ampliada da sociedade, é importante relacionar como o símbolo da aliança surge na teoria maussiana do simbolismo:

Ora, esta [a aliança] não é outra coisa senão a do político. A questão sobre a qual Mauss encerrava o Ensaio sobre o dom. Pois tudo em Mauss leva de fato a esta questão do político [...] os símbolos só têm vida e significação enquanto representam, comemoram, performam ou renovam um dom, uma ad-sociação ou, de modo mais geral, o político. Enquanto podem ser compreendidos e portanto traduzidos uns nos outros (Idem, pp. 251-253).

Ou seja, a passagem de um entendimento do dom como uma regra rígida para uma leitura pósestruturalista, que o compreende como uma significação da aliança, abre inevitavelmente perspectivas promissoras de uma aproximação dos estudos sobre o dom com o interacionismo crítico. Este entendimento da teoria do dom dentro de uma tradição teórica compreensiva e fenomenológica, que dialoga em diferentes níveis com as sociologias de Simmel, de Weber, de Schutz e do interacionismo simbólico, sobretudo o de Goffman, é importante para situarmos os caminhos de investigação possíveis a partir do dom. A compreensão e a explicação deste sistema não pressupõem o estudo do indivíduo nem do grupo, tampouco o estudo dos planos macro ou microssociológico, considerados isoladamente. A idéia da sociedade como um "fato social total" explica-se pelo valor da circulação das coisas entre os indivíduos e os grupos.

Nesse sentido, ao fazer a crítica aos limites da teoria marxista sobre o trabalho, Vandenberghe esclarece - reiterando comentário de Godbout (1998b) a este respeito - que o valor da dádiva não é ligado nem ao uso nem à troca, mas ao vínculo, ao relacional, reforçando a compreensão interacionista da dádiva. Assim, conclui: "Invertendo a caracterização do fetichismo da mercadoria feita por Marx, poderíamos dizer que as relações entre as pessoas (na dádiva) não mais aparecem como uma relação entre coisas, mas que as relações entre coisas agora aparecem como uma relação entre pessoas" (Vandenberghe, 2004, p. 110). Esta observação é interessante para entendermos que, ao se enfatizar a relação entre pessoas na dádiva, a circulação dos objetos, ou o "espírito das coisas" - o hau, dos antigos -, tanto pode reforçar práticas emancipatórias como, ao contrário, práticas conservadoras. Tudo depende, logo, da vivência da associação e da aliança, o que nos leva necessariamente a articular, no sistema do dom, interação e experiência vivida, sociologia interativa e sociologia fenomenológica.

Os estudos sobre a dádiva despertam, inevitavelmente, certa curiosidade sobre a ação social direta, sobre as modalidades de existência das práticas sociais no plano microssocial. Isto não anula, todavia, o interesse da teoria da dádiva para os estudos macrossociológicos, das organizações formais. Na verdade, quando nos debruçamos sobre os requisitos da confiança entre atores sociais e agentes institucionais no interior de organizações como as burocrático-legais ou, então, as mercantis, ou ainda nas práticas do mundo do trabalho, observamos que esta confiança não pode ser obtida nem pelas cláusulas contratuais livres entre parceiros, nem pela obrigação legal. Ao contrário, a confiança exige certo risco, qual seja, o de acreditar que aquele outro com quem me relaciono não vai me trair, embora nada assegure isso. Há 
um risco inerente ao dom pelo fato de não haver certeza de que o donatário vai receber a ação ou vai retribuí-la. Tudo é possível! (Fixot, 1994, p. 187). Este risco não pode ser simetricamente calculado, ele está aberto às incertezas. Isto explica, portanto, o interesse dos parceiros comerciais ou dos agentes burocráticos de que as pessoas se conheçam, que tenham antecedentes de honestidade e lealdade. Pois, no lado contrário, sob o peso da desconfiança e da corrupção, os sistemas formais inevitavelmente se degradam.

Mas, é certamente no âmbito das relações interpessoais que a dádiva aparece com maior nitidez. Porque é no plano da ação direta que se constrói primeiramente a sociedade, onde são edificadas as bases intersticiais das organizações formais e informais. Ali, nascem as redes sócio-humanas - sistemas de trocas diretas entre familiares, vizinhos e amigos -, as quais existem de maneira subjacente a outras redes, como as sociotécnicas - que aparecem como exigência de gestão das organizações formais - ou as socioinstitucionais que aparecem como exigência de governança entre Estado e sociedade civil, envolvendo agências governamentais e não-governamentais (Martins e Fontes, 2004).

O mercado de trabalho também não pode funcionar a contento caso patrões e empregados, ou produtores e consumidores, desconfiem das intenções uns dos outros. Em todos esses casos, os contratos devem ser legitimados por um mínimo de confiança no outro, uma aposta indiscutível no dom, de modo que o interesse objetivo revelado pela mercadoria ou pela lei possa aparecer como algo natural, como se o contrato encerrasse em si mesmo uma cláusula oculta de confiança e respeito, o que é falso. Isto é, apesar de o dom funcionar mais visivelmente nas socialidades primárias, ${ }^{19}$ ele continua a aparecer como recurso fundamental para permitir, no plano das socialidades secundárias, que os parceiros dos campos mercantil ou burocrático se disponham a incorporar livremente as regras do jogo, como se confiar nas regras sem duvidar de sua validade fosse algo eminentemente natural. A dádiva funciona, assim, em geral, nos dois registros, o primário e o secundário, embora tenha maior visibilidade no primeiro.

\section{Dom e vida associativa}

A contribuição de Mauss para a crítica teórica se faz pela demonstração de que o dom não é apenas uma teoria ingênua, fundada supostamente sobre as intenções generosas e altruístas do ser humano, servindo para repensar o conjunto das instituições sociais a partir dos seus fundamentos morais e normativos que variam de sociedade para sociedade. As tentativas de estigmatizar o sistema do dom como uma teoria ingênua, escondem preconceitos e ignorância a respeito de um pensamento que se apóia num sistema de motivações complexas da ação social. A teoria do dom constitui uma saída teórica importante para dar conta da complexidade e da diversidade das motivações sociais, inclusive aquelas utilitárias, presentes na vida cotidiana.

Mauss não rejeita, simplesmente, as teses liberais. Ao contrário, ele buscou esclarecer que o interesse é um motivo importante da prática social, mas que a própria idéia de interesse é complexa, na medida em que, além do interesse materialista e calculista, pode-se falar de interesse pela honra e pelo poder não apenas em função de si mesmo mas também para o outro. Na vida real, o interesse do sujeito não se centra, necessariamente, apenas na sua própria pessoa, mas na de todos com quem mantém interação na vida privada ou na vida pública. Cada um de nós revela, em algum momento da vida cotidiana, um interesse que transcende $\mathrm{o}$ ego e se transporta para o outro - seja ele alguém da família, um conhecido ou um mero desconhecido -, e este tipo de ação se faz, no mais das vezes, de forma espontânea. Não custa lembrar que tal compreensão ampliada do motivo do interesse não tem apenas valor teórico, mas prático, uma vez que pode impactar favoravelmente a reconfiguração das políticas públicas e de novas modalidades de participação da sociedade civil na organização da esfera pública, por exemplo.

O caráter paradigmático do sistema do dom traz uma contribuição inestimável para repensar as abordagens teóricas e metodológicas na sociologia, em diversos campos: do trabalho, da família, da religião, do desenvolvimento e da política, entre outros. De fato, a idéia da sociedade como um "fato social total" fabricado a partir de bens simbólicos e materiais não apenas amplia o en- 
tendimento da ação social, como permite, igualmente, se atravessar mais facilmente as fronteiras interdisciplinares, tudo em benefício de um pensamento moral e político mais complexo. Para isso, é importante chamar a atenção sobre o fato de que a teoria do dom é eminentemente relacional, não se fixando, por conseguinte, nem na estrutura nem na agência, mas no ciclo incessante de prestações e contraprestações de bens materiais e simbólicos. O ciclo de endividamento simbólico suscitado pela circulação de bens (bens simbólicos, como intenções, gestos, gentilezas e rituais, e bens materiais, como serviços a terceiros, auto-ajuda, utensílios ou mesmo mercadorias) institui necessariamente vínculos e alianças que estão na base da produção das identidades, dos lugares e das estruturas.

Em contrapartida, quando alguém deixa de cumprir as expectativas coletivas geradas pelo endividamento mútuo (ao se aceitar algo de alguém, necessariamente entramos em dívida com esta pessoa, mas, caso não queiramos manter a reciprocidade, basta não retribuirmos o gesto, a intenção ou o bem dado) desfaz-se o vínculo e a aliança. Esta compreensão dinâmica da ação social tem, na prática, o mesmo efeito que significa a passagem da descrição da realidade externa, de um momento inicial em que ela é apreendida, como uma fotografia, para um outro momento, em que é apreendida pelas imagens de um vídeo.

A perspectiva de sistematização de uma nova leitura do dom tem pertinência clara no sentido de enfatizar o valor do fato associativo e do movimento associacionista (Martins, 2005; Chanial, 2001) e/ou a importância de se pensar um novo paradigma da ação coletiva que enfatize o valor da solidariedade e da participação na sociedade civil. Esta observação é mais do que justificada num mundo globalizado, em que crescem as demandas por reconhecimento, por participação e por inclusão e as reações violentas pelas recusas desses direitos à cidadania e à vida saudável.

No desenvolvimento de uma sociologia do dom, prestamos especial ênfase ao modo de organização das socialidades primárias, isto é, à esfera microssociológica, com a intenção de verificar as perspectivas de construção de uma discursividade crítica no interior delas, via redes locais, como a família, a vizinhança e as associaçôes. Uma discursividade que considere tanto o confronto de sabe- res diferenciados (técnicos e populares) como as negociações e as alianças alinhavadas entre agências governamentais, não-governamentais (ONGs, Igrejas), associações de bairro e atores sociais, no âmbito local.

O desafio, no fundo, é observarmos se as possibilidades inscritas nas redes sociais existentes nas municipalidades e nas comunidades são suficientes para incrementar o surgimento de práticas associativas mais horizontais e abertas a novas modalidades de solidariedade e de cooperação, práticas essas que legitimam o surgimento de uma esfera cívica e pública politicamente consistente. Pois, apenas a partir de uma esfera com esta característica, isto é, ancorada nas trocas diretas, é possível pensar numa experiência de cidadania democrática ampliada, plural e participativa, que respeite as diferenças e as universalidades dos sistemas simbólicos e de poder.

\section{Contribuição da teoria do dom para a crítica do pensamento utilitarista hegemônico}

A força do dom como "princípio ativo" de uma crítica teórica capaz de se contrapor à doutrina utilitarista dominante ficou tolhida, já dissemos anteriormente, pelo modo como a antropologia estrutural traduziu o dom no seu próprio domínio conceitual, limitando, por conseguinte, seu impacto à análise das sociedades tradicionais e inibindo a compreensão do seu potencial para o entendimento das sociedades contemporâneas.

Mas, com a crise do estruturalismo no contexto da globalização de idéias nos fins dos anos de 1970, houve um maior intercâmbio de pesquisadores, gerando uma aproximação fértil, geográfica, temática e conceitual das grandes escolas do pensamento humanista, sobretudo as francesa, anglosaxônica e germânica. No que diz respeito especificamente à escola francesa de sociologia, a crise do estruturalismo permitiu resgatar a contribuição de Mauss a partir de uma crítica cultural e social renovada pela filosofia política francesa e pela filosofia analítica inglesa, a primeira enfatizando o tema da democracia, a segunda, o tema da linguagem da vida cotidiana. Nessa mesma direção, a aproximação da tradição renovada de Mauss com o interacionismo norte-americano, nos anos de 
1980, permitiu flexibilizar a vinculação excessiva do dom com a obrigação moral coletiva, o que abriu caminho para realçar o papel da liberdade individual ou do dom do indivíduo na constituição da prática social. Em suma, o debate que se sucede à crise do estruturalismo propiciou compreender que o sistema do dom aplica-se, igualmente, às sociedades tradicionais e às modernas, às sociedades fundadas em crenças a-históricas e àquelas fundadas na criação histórica, sendo ele peça central para se repensar a economia, a política e a democracia numa perspectiva antiutilitarista.

O reconhecimento do valor do dom para a explicação da sociedade moderna individualista implica, necessariamente, que os motivos fundamentais das prestações e das contraprestações humanas não são apenas de caráter obrigatório e dados pelas crenças e tradições, como verificamos nas sociedades tradicionais estudadas pelos antropólogos clássicos. Semelhantes motivos são também de caráter livre e espontâneo, gerados pelos desejos e utopias de indivíduos e grupos sociais, como é próprio das sociedades contemporâneas. Do mesmo modo, os indivíduos e pessoas morais não se relacionam apenas pelo interesse por si, mas pelo interesse pelo outro, ou, então, interesse pelo poder, ou pela honra ou pelo prestígio. Enfim, ao se desprender da imagem egoísta e individualista, o interesse torna-se "desinteressamento", ou seja, interesse que se desprende de sua referência para se tornar outra referência de si ou interesse do outro (Caillé, 2006).

Por conseguinte, mais do que uma mera atualização do sistema do dom, este reconhecimento da presença de motivos variados da ação humana aponta para uma crítica teórica de valor moral indiscutível. Esse projeto intelectual re-humanizante, que está presente na obra de Mauss, não é um fato isolado. Ele se cruza, na verdade, com outras contribuições relevantes para esse tipo de crítica ao reducionismo utilitarista e ao pensamento objetivista, como aquelas oferecidas ao longo do século XX por autores como Simmel, Mead, Merleau-Ponty, Goffman, Habermas, Castoriadis, Lefort, Taylor, entre outros. No seu conjunto, as obras desses autores evidenciam o valor da liberdade para a emancipação do ser humano, mas a partir de um lugar diverso daquele do liberalismo clássico, que é basicamente centrado no interesse individual. Tal diferença se evidencia pelo fato de que esses autores entendem a liberdade como um motivo que extrapola o mero interesse individual ou grupal, para encerrar um valor humano coletivo imprescindível para uma perspectiva democrática e participativa ampliada.

A leitura do Ensaio sobre a dádiva a partir da ótica de um sistema teórico interdisciplinar mais amplo - que incorpora, paradoxalmente, motivos diversos da ação humana, como os de liberdade e obrigação, do interesse e do desinteresse - permite introduzir uma série de inovações significativas para o pensamento humanista crítico. Para atingir o dogma utilitarista, Mauss buscou demonstrar, por exemplo, o equívoco de reduzir as origens da vida social à idéia de uma "economia natural", fundada numa representação abstrata denominada homo oeconomicus, como propõem os economistas clássicos.

$\mathrm{Na}$ crítica ao utilitarismo materialista, em conseqüência, Mauss buscou reinterpretar a economia do mercado com base em uma abordagem socioantropológica e interacionista mais ampla, pela qual o mercado é visto como um mecanismo de regulação entre outros. Tal opção teórica levou-o a rediscutir em profundidade outras noções complementares, como aquelas relacionadas ao contrato, ao trabalho e à utilidade, e novas modalidades de compreensão e interpretação da realidade vivida que, no seu conjunto, revelam uma complexa teoria das motivações humanas. Por isso consideramos que o sistema da dádiva encerra as bases de uma ciência moral de caráter interdisciplinar, fundamental para o avanço do novo movimento teórico nas ciências sociais, sem negligenciar a contribuição decisiva do estruturalismo na demonstração do simbolismo para as práticas culturais e sociais.

\section{NOTAS}

1 Numa primeira aproximação, a título de esclarecimento para os que não são iniciados no assunto, podemos dizer que o sistema do dom consiste num conjunto de prestações e contraprestações que se expandem ou se retraem mediante uma tríplice obrigação - doação, recepção e retribuição 
de bens materiais e simbólicos -, sendo constatada sua presença em todas as sociedades existentes, tradicionais e modernas, conforme deduzimos da leitura de Marcel Mauss.

2 Para Alain Caillé, os dois outros paradigmas, o individualista e o holista, apresentam-se sempre como verdades abstratas e intemporais. Função, estrutura, valores e cálculo, interesse individual e boas razões apresentar-se-iam sempre pelas mesmas modalidades independentemente de tempo ou lugar. Em contrapartida, o paradigma do dom deixa tudo aberto às investigações histórica, etnológica ou sociológica sem trazer respostas prontas. Nesse sentido, o dom seria antiparadigmático (Caillé, 2002b, p. 81).

3 Segundo Axel Honneth, a tese de Durkheim sobre a divisão do trabalho social é um insight importante para a compreensão da solidariedade social, na medida em que demonstrou que tal solidariedade nas sociedades modernas depende das formas democráticas e reflexivas da divisão do trabalho (Honneth, 2002, p. 275). Ora, tal releitura é curiosa, uma vez que as teses de Durkheim sobre a divisão do trabalho eram vistas como provas de um funcionalismo que fazia do fundador da sociologia francesa um autor, sob certos aspectos, suspeito. A retradução de Honneth traz novas luzes sobre o tema.

Evidentemente, estamos nos referindo aqui à tradição do catolicismo tradicional. Pois, no lado oposto, vimos surgir no Brasil, a partir da segunda metade do século XX, uma outra tradição religiosa católica, como a da Teologia da Libertação, que defende a reinterpretação de temas importantes, como o da caridade, com impactos positivos sobre o socialismo associativo de movimentos como, por exemplo, o MST e o da economia solidária.

5 O papel do pai da antropologia estrutural na formulação de uma certa leitura do dom pode ser mais bem compreendido a partir do esclarecimento fornecido a este respeito pelo sociólogo canadense Marcel Fournier, o mais importante biógrafo de Mauss. Num fórum especial sobre as "Novas Sociologias", no Encontro Anual da Anpocs, em 2004, Fournier esclareceu que Lévi-Strauss, em uma carta a um amigo, teria dito que Mauss teve o mérito de chegar até o rio, mas ele, Lévi-Strauss, é que teria feito a travessia das águas. Embora esta afirmativa sirva para reforçar a vinculação de Mauss com a antropologia estrutural, ela é, em si, insuficiente. Não pelo fato de que Lévi-Strauss não tenha feito bom uso do sistema teórico do dom, mas porque este sistema se abre para outros usos e entendimentos, e, sobretudo, para a construção de uma crítica teórica e moral mais ampla.

6 Como veremos mais adiante, ao realçar a ambivalência da ação social o dom permite demonstrar que as motivações humanas não podem, em absoluto, se limitar à função do egoísmo e do interesse material.

7 Contra um pensamento operacional, próprio da antiga ciência experimental de base cartesiana que entende a criação humana como o produto de um processo de informações concebido sobre o modelo da máquina humana, Merleau-Ponty propõe, na sua última obra escrita em vida, L'oeuil et l'esprit, um corpo que acorde outros corpos associados, os "outros" que não são meus congêneres (Merleau-Ponty, 1964a, pp. 12-13). E porque o corpo vê e se move, ele tem as coisas em torno de si mesmo; elas (as coisas) estão incrustadas na própria carne como um anexo ou um prolongamento dele, fazendo parte da definição plena do corpo, sendo que o mundo é feito do próprio corpo (Idem, p. 19).

8 Souza escapa dos perigos do culturalismo, presentes nessas narrativas que insistem sobre a originalidade, recorrendo com oportunidade à genealogia do indivíduo moderno realizada por Charles Taylor em A fonte do self (2005). Tal recurso facilita explicar que a noção de indivíduo é complexa e contraditória e que o self pode conhecer diferentes formas generalizantes, que não se reduzem nem àquela do individualismo moderno ocidental (Souza, 2001a, p. 182) nem a de leituras dicotômicas e culturalistas sobre a pessoa moral. Não cabe aqui entrar nesta discussão riquíssima da ontologia moral do Ocidente, formulada por Taylor, mas é necessário sublinhar sua pertinência para o que aqui estamos discutindo, a saber, que a genealogia do trabalho intelectual e a consideração pela análise reflexiva das condições lingüísticas, culturais, emocionais e, sobretudo, morais, presentes no vivido, são decisivas para se delimitar a construção do conhecimento num certo lugar e num certo tempo.

9 Clifford Geertz, com base em sua vasta experiência de antropologia comparada, oferece mais elementos para situar este debate sobre a ação intelectual no "terreno". Afirma ele que nossa compreensão de nós mesmos e de outros - nós mesmos entre outros - "é influenciada não apenas pelo intercâmbio com nossas próprias formas culturais mas, também, e de maneira bastante significativa, pela caracterização que antropólogos críticos, historiadores e outros, fazem das formas culturais que nos são alheias, transformando-as, 
depois de retrabalhadas e redirecionadas, em secundariamente nossas" (Geertz, 2001, pp. 17-18). Geertz está pensando aqui nas vicissitudes do antropólogo no "terreno" e dos perigos de se fazer "imaginação moral" esquecendo-se do imperativo da diversidade cultural.

10 Já há material relevante disponível na Revue du Mauss sobre a produção teórica pós-estruturalista nos últimos 25 anos. No Brasil, porém, o trabalho de retradução dos estudos sobre o dom ainda necessita de maior visibilidade acadêmica, embora iniciativas práticas venham ocorrendo nas grandes associações científicas como Anpocs, SBS Sociedade Brasileira de Sociologia e a ABA - Associação Brasileira de Antropologia.

11 A idéia de totalização do social, que propõe Mauss a partir do dom e que será discutida mais adiante, implica, lembra Karsenti, num importante deslocamento epistemológico que apresenta Mauss como peça fundamental no nascimento da lingüística que, como se sabe, foi fundada oficialmente por Saussure no seu Cours de linguistique general, ministrado no ano de 1916 (Karsenti, 1994, p. 88).

12 "Agora, é o indivíduo que é a fonte da mudança social. Ele sempre foi, mas não o sabia. As leis eram decididas por seus príncipes e suas religiões. Seus costumes pareciam-lhe sair de suas técnicas. E estas últimas estavam cravadas no artesanato, permitindo-lhe mais a ingeniosidade do que a inovação. O engenheiro surgiu lentamente com as primeiras máquinas. $\mathrm{E}$ as sociedades modernas mudam rapidamente como nunca antes visto. Trata-se, mesmo considerando todas as dificuldades, da ação do indivíduo" (Mauss, 2004, p. 140).

13 Esta crítica, que tem uma significação preciosa, tanto cultural como também social e política, aproxima Mauss de outro grande teórico antiutilitarista do século XX, Karl Polanyi, que demonstrou na sua obra clássica, A grande transformação, a dependência estreita da economia de mercado com a cultura histórica de uma época e de uma determinada civilização.

14 A sigla M.A.U.S.S. tem dois significados: prestar uma homenagem a Marcel Mauss, um dos fundadores da escola francesa de sociologia e sintetizar o descontentamento de um grupo de intelectuais com a "fragilidade da ciência econômica e de suas pretensões explicativas" (Caillé, 1989, p. 7). No início, antiutilitarismo significava apenas antieconomicismo. Na declaração de intenções do M.A.U.S.S, os signatários do documento assinalam que "o objetivo do movimento era sobretudo de relançar ou de lançar uma discussão e uma informação científica sobre a questão das dimensões não mercantis e não monetárias da troca". "Não se trata de opor a axiomática do interesse a um certo espiritualismo do desprendimento, da gratuidade ou da ação não finalizada, mas de opor a esta axiomática limites precisos de legitimidade, tanto atuais como passadas, metodológicas e antropológicas. Para isto, importa reabrir o debate que havia sido iniciado sobretudo por Mauss, Malinowski e Polanyi [...]" (Bullletin du MAUSS, 1982, p. 9). Apenas nos fins da década de 1980, esta crítica antiutilitarista difusa transforma-se numa crítica antiutilitarista propositiva, que elege o sistema do dom como veículo central para se avançar na desconstrução do caráter restritivo das teses economicistas dominantes, e na crítica à proposta ingênua da economia de mercado como uma economia natural que existiria desde sempre, estando hipoteticamente na origem e no desenvolvimento de todas as sociedades humanas.

Nesse sentido, a crítica antiutilitarista de Mauss fica muito próxima daquela empreendida por um filósofo moral da contemporaneidade, Charles Taylor. Para este autor, o utilitarismo clássico equivoca-se ao tentar rejeitar as distinções qualitativas e hiperdimensionar a quantificação e o cálculo (Taylor, 2005, p. 39). Ambos os autores buscam desnaturalizar o utilitarismo e provar a existência de uma fundamentação moral por trás das motivações utilitaristas. Mauss critica a idéia de uma economia natural, que existiria desde sempre; Taylor, ideais como o self desprendido que, ao objetivar o mundo circundante, inclusive as emoções, produz uma espécie de distanciamento e agir instrumental sobre o mundo, que gera ilusões como a da economia natural, por exemplo. Ambos sublinham uma "valorização forte" (noção proposta por Taylor) dos bens à nossa disposição, no sentido de que tais bens precisam de uma distinção qualitativa, uma vez que, lembra Taylor, eles funcionam "em algum sentido como padrão para nós” (Idem, p. 36).

16 A valorização do simbolismo não significa a desconsideração dos condicionantes sociais, históricos e mesmo biológicos do ser humano. Ao contrário, amplia a compreensão do sujeito humano ao permitir sair de uma concepção objetivista para uma outra mais ampla, que integra os planos da interioridade e das redes de inserção do self no mundo. Pelo simbolismo pode se compreender, enfim, que as próprias nomeações desses condicionantes - o que chamamos de biológico, corporal, objetivo ou subjetivo - varia de cultura para cultura e depende dos esquemas perceptivos 
prevalecentes em diferentes sociedades. Esta idéia de uma corporeidade humana como fenômeno social e cultural, como motivo simbólico é bem desenvolvida em $A$ sociologia do corpo, de David Le Breton (2006).

17 Em Fenomenologia da percepção Merleau-Ponty critica o dualismo cartesiano e a exaltação que ele considera ilusória da separação entre sujeito e objeto. Pensa ele, diferentemente, que tudo que o indivíduo percebe é extensão dele, e o olhar objetivado - que cria a ilusão da separação entre o sujeito e o objeto - é secundário com relação à sua expressividade, a seu "sentir total" que engloba o subjetivo e o objetivo. Para o autor, tal separação apenas é possível, do ponto de vista lógico, pela leitura simplificada da percepção fenomenal que enfatiza a exterioridade do corpo, produzindo uma "imagem empobrecida" do verdadeiro corpo, que apenas se revela integralmente na sua expressão fenomenal (Merleau-Ponty, 1999, p. 493). Pensamos que a idéia de sentir total deste filósofo está intimamente ligada àquela de fato social total de Mauss.

18 No número especial de comemoração dos dez anos de fundação do Boletim do MAUSS (depois transformado em revista), em 1992, intitulado "Dez anos de evolução das ciências sociais: metamorfose do MAUSS", Alain Caillé propõe, num texto provocativo intitulado "É preciso criar uma nova disciplina nas ciências sociais e qual?”, a fundação de uma filosofia política que teria a eficácia da ciência. Para ele, a filosofia política atual seria a melhor representação de um modelo normativo para as ciências sociais (Caillé, 1992, p. 40). Sem desconsiderar esta proposta, pensamos todavia que os avanços no debate sobre o dom desde então têm revelado existir uma força moral que termina se impondo ao elemento político, embora nele se inspire para assegurar a sua aderência normativa e prática. Daí considerarmos que a expressão "ciência moral humanista" pode também ser apropriada para pôr em relevo a questão dos incondicionantes da ação social e sua importância na constituição da aliança e, também, da democracia.

19 Inspirado nos estudos sobre o dom, Caillé propõe haver uma tendência da sociedade moderna a provocar a separação crescente entre dois registros de socialidades, que permanecem bastante imbricados em sociedades mais tradicionais. O primeiro registro é o das socialidades primárias, no qual as relações entre as pessoas são mais importantes do que os papéis funcionais que elas desenvolvem. Trata-se do registro da família, dos parentes, dos amigos e dos vizinhos. No registro das socialidades secundárias, ao contrário, a funcionalidade dos atores sociais vale mais do que suas personalidades, como se observa nas práticas do mercado, do Estado e da ciência. Nenhuma administração governamental pode funcionar caso não exista o espírito do serviço público, assim como uma pátria não sobrevive caso ninguém se disponha a morrer por ela (Caillé, 2002a, p. 196). O mesmo se pode dizer do serviço médico. Os hospitais e as clínicas médicas não podem funcionar eficazmente caso não haja algum tipo de solidariedade entre médicos, enfermeiras, funcionários e familiares em torno do sofrimento do doente, espelhando, em cada personagem envolvido, a proximidade inexorável da morte e da finitude.

\section{BIBLIOGRAFIA}

ALEXANDER, J. (1987), "O novo movimento teórico". Revista Brasileira de Ciências Sociais, 2 (4): 5-28jun.

BAECHLER, J. (2002), "Naturalité, universalité, objectivité". La Revue du M.A.U.S.S: Y a-t-il des valeurs naturelles?, 19: 51-64.

BATESON, G. (1977), Vers une écologie de l'esprit. Paris, Éditions du Seuil, vol. 1.

CAILlÉ, A. (1989), Critique de la raison utilitaire. Paris, La Découverte.

(1992), "Faut-il créer une nouvelle discipline dans les sciences sociales, et laquelle? La Revue du MAUSS: dix ans d'évolution des sciences sociales, 15-16: 11-42.

(1998), "Nem holismo nem individualismo metodológicos: Marcel Mauss e o paradigma da dádiva". Revista Brasileira de Ciências Sociais, 13 (38): 5-37.

(2002a), "Dádiva e associação", in P. H. Martins (org.), A dádiva entre os modernos: discussão sobre os fundamentos e as regras do social, Petrópolis, Vozes.

(2002b), Antropologia do dom: o terceiro paradigma. Petrópolis, Vozes.

(2006), "O dom entre interesse e 'desinteressamento"”, in P. H. Martins e R. 
Campos (orgs.), Polifonia do dom, Recife, Editora da UFPE.

CAILlÉ, A. \& GRAEBER, D. (2002), "Introdução", in P. H. Martins (org.), A dádiva entre os modernos: discussão sobre os fundamentos e as regras do social, Petrópolis, Vozes.

CHANIAL, P. (2001), Justice, don et association: la délicate essence de la démocratie. Paris, La Découverte/M.A.U.S.S.

COHN, G. (1998), "As diferenças finais: de Simmel a Luhman". Revista Brasileira de Ciências Sociais, 13 (38): 53-62.

CORCUFF, P. (2006), "La question démocratique entre pressuposés philosophiques et défis individualistes", in Alain Caillé (org.), Quelle démocratie voulons-nous? Pièces pour um débat, Paris, La Découverte.

DOSSE, F. (1997), L'empire du sens: l'humanisation des sciences humaines. Paris, La Découverte.

DURKHEIM, E. (2004a), Da divisão do trabalho social. São Paulo, Martins Fontes.

. (2004b), Pragmatismo e sociologia. Florianópolis, Editora da UFSC/Editora da Unisul.

FIXOT, A.M. (1994), "Le don à la croisé du symbolique et du possible". La Revue du MAUSS (A quoi se fier? Confiance, interaction et théorie des jeux), 4: 176-189.

FOURNIER, M. \& MARCEL, J-C. (2004), "Présentation: avec Mauss et au-délà de Mauss". Sociologie et Sociétés, XXXVI (2): 5-14.

GEERTZ, C. (1997), O saber local. Petrópolis, Vozes.

GODBOUT, J. (em colaboração com A. Caillé). (1998a), O espírito da dádiva. Rio de Janeiro, FGV.

(1998b), "Introdução à dádiva". Revista Brasileira de Ciências Sociais, 13 (38): 39-51.

(2000), Le don, la dette, l'identité. Paris, La Découverte/M.A.U.S.S.
(2002), "Homo donator x homo oeconomicus", in P. H. Martins (org.), $A$ dádiva entre os modernos: discussão sobre os fundamentos e as regras do social, Petrópolis, Vozes.

GODELIER, M. (2004), Métamorphoses de la Parente. Paris, Fayard.

GRAEBER, M. (2006), "O comunismo de Marcel Mauss", in P. H. Martins e R. Campos (orgs.), Polifonia do dom, Recife, Editora da UFPE.

HONNETH, Axel. (2002). "A interview with Axel Honneth: the role of socioology in the theory of cognition". European Journal of Social Theory, 5 (2): 265-277 [organização de A. Petersen e R. Willig].

KARSENTI, B. (1994), Marcel Mauss: lê fait social total. Paris, PUF.

LA REVUE DU M.A.U.S.S. (1995), Qu'est-ce que l'utilitarisme? Une énigme dans l'histoire des idées, 6, $2^{\text {ème }}$ semestre.

LE BRETON, D. (2006), A sociologia do corpo. Petrópolis, Vozes.

LÉVI-STRAUSS, C. (1982), As estruturas elementares do parentesco. 3 ed. Petrópolis, Vozes.

(2003), "Introdução à obra de Marcel Mauss", in M. Mauss, Sociologia e antropologia, São Paulo, Cosac\&Naify.

MARTINS, P. H. (2005), "A sociologia de Marcel Mauss: dom, simbolismo e associação". Revista Crítica de Ciências Sociais, 73: 45-66, dez., Coimbra.

MARTINS, P. H. \& FONTES, B. (2004), "Construindo o conceito de rede de vigilância em saúde", in Redes sociais e saúde: novas possibilidades teóricas, Recife, Editora da UFPE, pp.103-120.

MAUSS, M. (2003), Sociologia e antropologia. São Paulo, Cosac\&Naify [edição francesa: MAUSS, M. (1999), Sociologie e anthropologie. 8 ed. Paris, PUF].

MERLEAU-PONTY, M. (1960), "De Mauss à Claude Lévi-Strauss", in Éloge de la philosophie, Paris, Gallimard. 
(1964a) L'oeuil et l'esprit. Paris, Gallimard.

(1964b), Le visible et l'invisible. Paris, Gallimard.

(1999), Phénomenologie de la perception. Paris, Gallimard.

PAPILLOUD, C. (2004), "Trois épreuves de la relation humaine: Georg Simmel et Marcel Mauss, précurseurs de l'interactionnisme critique". Sociologie et Sociétés, XXXVI (2): $55-72$.

PAULME, D. (2004), "Un ma"tre incomparable". Sociologie et Sociétés, XXXVI (2): 131-134.

POLANYI, K. (1983), La grande transformation: aux origines politiques et économiques de notre temps. Paris, Gallimard.

SABOURIN, E. (2004), "Dádiva e reciprocidade nas sociedades rurais contemporâneas". Tomo - Revista do Núcleo de Pós-Graduação e Pesquisa em Ciências Sociais, ano VII (75-103).

SARTI, C. (2005), “'Deixarás pai e mãe': notas sobre Lévi-Strauss e a família". Revistas Anthropológicas, ano 9 (16): 31-53.

SIGAUD, L. (1999), "As vicissitudes do "Ensaio sobre o dom'". Mana - Estudos de Antropologia Social, 5 (2): 89-124.

SOUZA, J. (2001a), "Democracia e personalismo para Roberto DaMatta: descobrindo nossos mistérios ou sistematizando nossos auto-enganos?", in __________ (org.), Democracia hoje: novos desafios para a teoria democrática contemporânea, Brasília, Editora da UnB.

. (2001b), "Gilberto Freyre e a singularidade cultural brasileira", in (org.), Democracia hoje: novos desafios para a teoria democrática contemporânea, Brasília, Editora da UnB.

TAROT, C. (1999), De Durkheim a Mauss, l'invention du symbolisme: sociologie et sciences des religions. Paris, La Découverte.

TAYLOR, C. (2005), As fontes do self. São Paulo, Loyola.
VANDENBERGHE, F. (2004), "Desvendando Marx: o marxismo e o fim da sociedade do trabalho", in P. H. Martins e B. F. Nunes (orgs.), A nova ordem social: perspectivas da solidariedade contemporânea, Brasília, Paralelo 15. 


\section{DE LÉVI-STRAUSS A M.A.U.S.S. - MOVIMENTO ANTIUTILITARISTA NAS CIÊNCIAS SOCIAIS: ITINE- RÁRIOS DO DOM}

\section{Paulo Henrique Martins}

Palavras-chave: Dádiva; Teoria social; Marcel Mauss; Movimento antiutilitarista.

Os estudos sobre o dom oferecem uma contribuição inestimável para a teoria social hoje, que ultrapassam os usos oferecidos pela antropologia estrutural. Eles são relevantes para se repensar o social e a política e permitem um diálogo em profundidade com várias outras correntes do pensamento. Ao se reavaliar o dom na atualidade, sobretudo a partir das novas leituras contemporâneas sobre o tema, como aquela oferecida pelo M.A.U.S.S. (Movimento Antiutilitarista nas Ciências Sociais), descortina-se também uma outra compreensão da escola sociológica francesa e de Marcel Mauss, em particular, o primeiro a sistematizar os estudos sobre a dádiva.

\section{FROM \\ LÉVI-STRAUSS \\ M.A.U.S.S. - ANTI-UTILITARIAN MOVEMENT IN THE SOCIAL SCI- ENCES: GIFT ITINERARIES}

\section{Paulo Henrique Martins}

Keywords: Gift; Social theory; Marcel Mauss; Anti-utilitarian movement.

Studies on the gift offer an invaluable contribution to the current social theory, surpassing utilizations offered by the structural anthropology. They are relevant for rethinking the social and politics allowing a deep dialog with many other thinking currents. In reevaluating the gift today, especially from the standpoint of new contemporary versions on the theme, such as the one offered by the so-called M.A.U.S.S. - Movimento Antiutilitarista nas Ciências Sociais (Anti-Utilitarian Movement in the Social Sciences), another comprehension of the French sociological school of is uncovered, particularly Marcel Mauss, the first one to systematize the studies on the gift.

\section{DE LÉVI-STRAUSS AU M.A.U.S.S. - MOUVEMENT ANTIUTILITARISTE DANS LES SCIENCES SOCIALES : ITINÉRAIRES DU DON}

\section{Paulo Henrique Martins}

Mots-clés: Don; Théorie sociale; Marcel Mauss; Mouvement antiutilitariste.

Les études sur le don offrent une contribution inestimable à la théorie sociale d'aujourd'hui, qui dépasse les usages offerts par l'anthropologie structurelle. Ils sont importants pour repenser le social et la politique et permettent un dialogue en profondeur avec plusieurs autres courants de pensée. Lorsqu'on évalue le don dans l'actualité, surtout à partir des nouvelles lectures contemporaines sur le sujet, comme celles proposées par le M.A.U.S.S. (Mouvement Antiutilitariste dans les Sciences Sociales), appara"t également une autre compréhension de l'école sociologique française et, particulièrement, de Marcel Mauss, qui a été le premier à systématiser les études sur le don. 